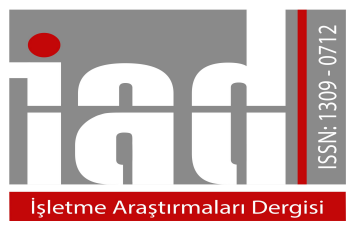

İ̧̧letme Araştırmaları Dergisi

Journal of Business Research-Turk

10/3 (2018) 321-349

Journal Of

Business Research

Turk

www.isarder.org

\title{
Havayolu İşletmeleri Mobil Pazarlama Uygulamaları Algısının Yolcuların Demografik Özellikleri Yönünden İncelenmesi Analysis of Airline Mobile Marketing Implementations' Perception As Per Passengers' Demographic Traits
}

\author{
Vahap ÖNEN \\ İstanbul Okan Universitesi \\ Uygulamalı Bilimler Fakültesi \\ Sivil Havacılık Yönetimi, İstanbul, Türkiye \\ orcid.org/0000-0001-8592-9430 \\ vahap.onen@okan.edu.tr
}

\begin{abstract}
Özet
Dijital teknolojilerin ilerlemesi ve bu gelişmelerin mobil uygulamalara yansıtılması tüketciler tarafından tarafından benimsenmiş ve hızla yaygınlaşmıştır. Pazarlama yönetimleri de tüketicilerin bu satın alama davranışlarına yönelik bu eğilimlerini dikkate alarak pazarlama programlarında mobil uygulamalara yer vererek bunların ortaya çıkardığı mobil pazarlama olanaklarından yararlanmaya başlamışlardır. Ticari havayolu yolcu taşımacılığı sektörü de, tüketicilere yönelik mobil uygulamaların en yaygın kullanıldığı sektörlerden bir tanesidir. Bundan dolayı bu çalışmanın amacı, havayolları mobil pazarlama uygulamalarının havayolu ile seyahat edenlerin demografik özellikleri yönünden nasıl algılandığını ortaya koymaktır. Konuya yönelik olarak havayollarından dijital ortamda bilet almış ve aynı zamanda yolcu olarak uçmuş tüketiciler üzerinde bir araştırma yapılmıştır. Yapılan çalışmada Aakay’ın 15 sorulu mobil pazarlama ölçeği kullanılmıştır. Ölçek çalışmaya uygun hale getirilmesi için faktör ve güvenirlik analizine tabi tutulmuştur. Yapılan faktör ve güvenirlik analizi neticesinde ölçekten 4 soru çıkartılarak 4 faktörde gruplandırılarak ölçek kullanıma hazır hale getirilmiş ve daha sonra ölçeğin her bir boyutuna ait değerler ile mobil mesaj alma sıklığ 1 , internette harcanan sürelerin ortalama değerleri belirlenmiştir. Akabinde, müşterilerin demografik özellikleri açısından mobil pazarlama algısının belirlenmesine yönelik " $t$ " testleri ve tek yönlü varyans analizleri yapılmıştır. Yapılan analizler sonucunda medeni durum ve yaş özelliklerine göre müşterilerin mobil pazarlama algılarında anlamlı farklılıklar olmadığı belirlenmiştir. Cinsiyete göre ise sadece mobil pazarlama boyutunda istatiksel olarak anlamlı fark tespit edilmiştir. Eğitim durumuna göre yapılan analizde tüm boyutlarda mobil pazarlama algısının anlamlı şekilde farklı algılandığ 1 görülmüş, gelir gruplarına göre yapılan analizde sadece mobil pazarlamanın satınalma kararlarına etkisi sürecinde anlamlı fark tespit edilmiş, mesaj alma sıklığına göre ise, mobil pazarlamanın satın alama kararlarına etkisi, mobil pazarlamaya yönelik
\end{abstract}


tutum ve mobil pazarlama faaliyetlerine genel bakış boyutlarında istatiksel olarak anlamlı farklar belirlenmiştir. Genel olarak değerlendirildiğinde bir çok demografik özelliğe göre üketiclerin mobil pazarlama algısının değiştiği belirlenmiştir. Bunlara ilave olarak yapılan ilişki analizinde, müşterilerin yaptıkları alışveriş miktarı ile yapılan harcamalar arasında, müşterilerin gelirleriyle yapılan harcamalar arasında, müşterilerin gelirleriyle yaş arasında, internette geçirdiği süre ile yapılan harcamalar arasında anlamlı pozitif ve olumlu yönde ilişkiler tespit edilmiştir.

Anahtar Kelimeler: Mobil Pazarlama Demografik Özellikler Havayolları

\section{Abstract}

By devolopped digital technolgy and applied these improvements on the mobile applications have been recognized by consumers and quickly have been wide-spreaded. Since the marketing management are aware of this consumer purchasing behaviours, havin seen this tendency, they put mobile applications to their marketing program in order to get benefit of mobile marketing activities. Commercial air passenger transportation is also one of the most common industry of use for mobile technologies. Therefore, the purpose of this study is to show how airline mobile marketing applications are perceived by customers in terms of their demographic traits. In terms of subject a research was condcuted by customers who previously were purchased airline ticket and at the same time flew. In the study Aakay's mobile marketing scale which consist of 15 questions was used. The scale was subjected to factor and reliability analysis to make it fit for the study. In the result of the factor and reliability analysis, 4 questions omitted from the list then four dimesioned scale was ready for analysis. Then, the average value of the each dimension of scale, the frequency of receiving mobile messages and the average time spent on the internet have been determined. Then, " $t$ " tests and one way analysis of variance were conducted to determine the mobile marketing perception in terms of the demographic characteristics of the customers. As a result of the analysis made, it was determined that there is no significant difference in customers' mobile marketing perceptions according to gender status and age groups. In the one-way Anova analysis made according to the educational status, it was determined that mobile marketing perception was perceived differently in all dimensions, according to the income groups; it was seen that there was a significant difference only in the effect of mobile marketing on purchasing decisions, according to the frequency of receiving messages, there were statistically significant differences in the dimensions of the impact of mobile marketing on purchasing decisions, the interest in mobile marketing and the overall view of mobile marketing activities. In generally summarized, it is found that mobile marketing perception has changed more than one demographic traits. Moreover, as per the result of pearson correlation analysis, it is determined that there are significant and positive correlations between purchased items and customer expenditures, between customers incomes and customers expenditures; between customers ages and customers incomes; beween avereage internet usage duration and customers expenditures.

Key Words: Mobile Marketing Demographic Traits Airlines 


\section{Giriş}

Bilgi ve iletişim teknolojilerindeki (BIT) hızlı gelişmeler özellike 1990'ların başlarından itibaren konaklama ve turizm endüstrisini büyük ölçüde etkilemiştir (Buhalis ve Law, 2008). BİT'lerin etkilerinin temel olarak sektörde ugulamalarına bakıldığında firmaların müşterilerine ulaşmalarını sağlayan önemli kanallar olan web siteleri, sosyal medya ve mobil teknolojilerden kaynaklanmakta olduğu görülmektedir (Leung, Law, van Hoof ve Buhalis, 2013; Sotiriadis, 2017). Sanal mobil işlemlerin ve BIT'lerin birarada kullanımları, akıllı telefonlar, tabletler ve mobil uygulamalar, tüketiclerin internete erişmeleri için birincil araçlar olarak yer alarak günlük yaşamlarının vazgeçilmez bir parçası haline gelmiştir (Wang, Park, ve Fesenmaier, 2012). Statista'nın (2017) tahminine göre akıllı telefon kullanıcılarının sayısı 2020 yılına kadar tüm dünyada 2,8 milyarı aşarak neredeyse dünya toplam nüfusunun üçte birinden fazlasını temsil edecektir. Tüketicilerin seyahat sebeplerinden dolay1 mobil teknolojilerin yaygın şekilde kabul görmesi mobil bilgi hizmetlerinin daha da geliştirilmesine yol açmaktadır. Mobil teknolojilerin uygulamaya yönelik sistemi geliştirenler lokasyon bazlı pazarlamayı sağlamak için küresel konumlandırma sistemlerinin (GPS) firsatlarından da yararlanmaktadırlar (Beldona, Lin ve Yoo, 2012; Mak, Nickerson ve Sim, 2015; Yoon, Kim ve Connolly, 2017).

\section{Literatür Taraması}

\subsection{Mobil Pazarlama}

Mobil pazarlamaya yönelik literaturde bir çok tanım mevcut olup; mobil kavramı çalışma alanında bulunulmadığı dışında ve seyahat esnasında görevlerini gerçekleştirmeye yönelik çalışmanın başa platformlara aktarılabilmesiyle alakalıdır (Yamamoto, 2011). Mobil Pazarlama Birliği (MMA) mobil pazarlamayı; işletmelerin müşterileriyle herhangi bir mobil cihaz ya da bağlantıyı kullanarak etkileşimli ve amacına uygun bir şekilde iletişim kurmasına ve yakın ilişkiler geliştirmesine olanak tanıyan uygulamalar dizisi olarak tanımlamaktadır (Mobile Marketing Association, 2009). Hareketlilik ve hareketliliğin ortya çıkardığı yer ve erişilmesk istenen gruba vaktinde ve doğrudan erişme firsatı, pazarlama yönetimini yeni bir konspete götürmüş ve pazarlama alanında yer almasını sağlamıştır (Karaca ve Gülmez, 2010). Mobil pazarlama, ürünlerin ve hizmetlerin bir mobil iletişim kanalı üzerinden pazarlanmasıdır. Bir başka tanıma göre; mobil pazarlama Pazar bölümünde yer alan hedef gurubuna direkt veya karşılıklı etkileşimli biçimde erişebilen kişisel, zaman ve mekâna hassas bir kanaldır (Gardlund, 2005, s. 11). Tüm kuruluşun menfaatelerini içerecek biçimde mobil iletişim ekipmanları vasıtasıyla malların, hizmetlerin ve fikirlerin promosyonu sürecinde yararlanılan kablo gerektirmeden etkili bir pazarlama aracı olarak da ifade edilmektedir (Scharl ve Dĭg., 2005). Diğer bir manada ise; mevcut müşterilerle vepoatnsiyel müşterilerle iletişim gerçekleştirmek için ürün, hizmet ve ek olarak düşüncelerin duyurulması için mobil vasıtaların ve kablosuz yayın araçlarının kullanılmasıdır. Mobil cihazlar birey ve dünya arasında aracı bir rol üstlenmenin yanı sıra yaşamı destekleyen bir vasıta olarak görülmekte ve kablosuz bir silah gibi bilgiyi ne zaman istenirse akıtan ve durduran bir rol üstlenmektedir (Aksu, 2007). Günümüzde bu pazarlama yöntemi, geleneksel pazarlama dağıtım kanallarına bir alternatif olarak ve geleceğin bütünleşik pazarlama iletişimi stratejilerine olası bir alan olarak değerlendirilmektedir (Karaçizmeler ve Güzeler, 2010, s. 12). Bu pazarlama yöntemi, ürünlerin satışlarını, servislerini ve bu ürün/servisler hakkında bilgi edinimini artırmak 
için mobil araçların kullanımıyla müşterileri ile iletişimde gerekli olan aktiviteler olarak adlandırılmaktadır (Karaca ve Ateşoğlu, 2006). Mobil pazarlama teknoloji odaklı pazarlamanın en hızlı büyüyen alanlarından biridir. Cep telefonları, masaüstü bilgisayarlar ve dizüstü bilgisayarlara oranla hem daha ucuzdur hem de taşınabilir cihazlardır. Özellikle üçüncü dünya ülkeleri olarak tanımlanan bölgelerde çoğu insan internet bağlantılı bir bilgisayara sahip değilken hemen hemen hepsi bir mobil cep telefonuna sahiptir. Video, ses ve fotoğraf paylaşımı, bloglama, internette sörf, e-posta erişimi ve dünyanın her yerinden insanlar ile iletişim bu teknoloji aracılığıyla gerçekleştirilmektedir. Müşteri ilişkileri yönetiminin verimli olarak yapıldığ1 mobil cihazların başında gelen cep telefonları, 3G teknolojisi, mobil TV ve görüntülü konuşma gibi özellikleri sayesinde, işletmeler için geleneksel pazarlama kanallarından daha kolay, hızlı ve verimli bir araç olarak mobil pazarlama uygulamaları ile satışların ve pazar payının arttırılmasına yardımcı olmakta ve yüksek düzeyde geri dönüş imkânı sunmaktadır (Türkiye Mobil Pazarlama Birliği, 201, s. 2). Literatürde mobil pazarlama kapsamında daha çok tüketici algılamalarına yönelik çalışmalar görülmüştür. $\mathrm{Bu}$ araştırmalarda tüketiciler, bilgilendirme, eğlendirme ve güvenilirlik ile olumlu bir tutum içindeyken, rahatsız edicilik ile olumsuz tutum içindedirler. Tüketicilerin en fazla etkisindekaldıkları mobil reklamın içeriği, hoş vakit geçirme, ötekileri ise güvenilirlik ve rahatsız vericilik olduğu tespit edilmiştir (Tsang, ve Diğ., 2004). Carol ve Diğ. (2007) mobil reklamların uygun görülmesinde önemli etkisi olan dört bileşen ifade etmiş olup bunlar; izin, içerik, servis sağlayıcının kontrolü, mesaj iletim frekansı şeklinde belirlenmiştir. Keshtgary ve Khajehpour (2011) ise, tüketicilerin mobil reklamlara olan tutumlarını, daha ziyade olumsuz bulduklarını ortaya çıkardılar. Fakay tüketciler izinli mobil reklamları kullanmayı tercih etmektedirler. Tüketiciler, cep telefonu hizmetlerini kullanmak istiyorlar,ancak hoş vakit geçirme, oyun ve iletişim hizmetlerinden yararlanmayı öncelikli olarak talep etmektedirler (Nysveen, ve Diğ., 2005). Tanakinjal, ve Diğ., (2010) ürün ve hizmetlerden yararlanan kişilerin davranışlarını etkileyen en önemli faktörün, mobil reklamların sunduğu olanaklar olduğunu belirlemiştir. Hanley, vd. (2006) üniversite öğrencilerinin çok büyük bir bölümü cep aracılığıyla reklam kabul etmede pek istekli olmadıklarını belirtmişlerdir. Fakat, özellikle maddi tdestekler sunulursa ve mobil reklamlar parasız olursa, mobil reklamların gönderilmesine hayıt dememektedirler. Porus ve Ricker (2007) bir çalışmalarında, 18 'den nüyük yaştaki mobil telefon kullanıcılarının \%78'i kullanıcıya para sağlayan, \%63'ü parasız konuşma dakikası sunan, \%40'1 parasız oyun ve müzikler yükleme ortamı sunan ve \%40'1 ise indirim kuponları sağlayan mobil reklamları kabul etmek istediğini belirlemiştir.

\subsection{Havayollarında Mobil Pazarlama Uygulamaları}

Hizmet sektöründeki son teknolojik gelişmeler, hizmet sunumunun adeta insanların yüz yüze veya kendi kendine hizmet sunumunu gerçekleştiren yapılara dönüşmesine yol açmıştır. Yapılan akademik çalışmalarda örneğin (Lu ve Diğ., 2009), mobil teknolojilerin uygulanması iş yapmanın yeni yollarını oluşturduğu ve müşteriler ve kuruluşlar arasındaki etkileşimi değiştirdiği ifade edilmiştir. Havayolu endüstrisinde de internet gibi kendi kendine hizmet sunan teknolojilerin kullanılması yoluyla, yolcular, çalışanlar ile doğrudan etkileşim yerine kendi başlarına hizmetleri kullanabilmektedirler (Ku ve Chen, 2013; Beatson ve Diğ., 2006; Elliott ve Diğ., 2012; Lim , 2012; Lu ve Diğ., 2009, 2011; Tam ve Lam, 2004). Yolcuların çoğu (\% 87) rezervasyon için mobil teknolojileri kullanmakta ve bunların yarısından fazlasının (\% 
54) dünya çapında check-in hizmetleri için kendi kendine hizmet veren teknolojileri tercih etmektedirler. (www.sita.aero, Airline IT Survey, 2017). Günümüzde, yolcular bu teknolojileri kullanarak artan bağımsızlık ve zaman / alan kısıtlamalarından bağımsız olarak kendilerini çok daha rahat hissetmektedirler. Bilgi ve İletişim Teknolojisinin ilerlemesiyle, akıllı telefonlar gibi mobil cihazlar tüketicilerin çeşitli servisler hakkında bilgi almak için internet'e erişmelerine olanak sağlanmaktadır. Havayolları, bu avantajlardan haberdardır ve işlerini, web sitelerini geliştirerek ve bireylerin mobil cihazlarına indirebilecekleri uçak bileti rezervasyon uygulamalarını sunarak zenginleştirmektedir. Bir çalışmada CAPA (2017), 2016 yılında, Malezya'da yaklaşık 68 milyon havayolu yolcusu olduğunu, 2017 yılında yolcu sayısında \% 15'lik bir büyümenin yaşanabileceğini, bu büyümenin özellikle de AirAsia, Air Asia X, Malezya Havayolları ve Malindo Air taşıyıcılarında olacağını öngörmekte olup bu taşıyıcıların, bilgisayar aracılığıyla "online" uçak bileti ve kredi / banka kartı (MasterCard, Visa), ücret kartı (American Express), PayPal, İdeal gibi mobil cihazlarda uçak bileti rezervasyon uygulamaları için çeşitli ödeme yöntemlerini kabul ettiklerini dikkat çekmektedir. Havayolları, seyahat süreci boyunca çeşitli işlevler sunan bir dizi mobil uygulama ve araç sunmaktadır (Pagiavlas ve Diğ., 2005). Tablo 1, ABD merkezli taşıyıcılar tarafından halen yürürlükte olan tüketici odaklı uygulamalara genel bir bakış sunmaktadır (Pagiavlas ve Diğ., 2005). Bu uygulamalar bilgi odaklı veya süreç odaklı olarak kategorilendirilebilir. Uygulamaların çoğu, genel veya uçuşa özgü olabilen bilgi odaklı uygulamalardır. Genel bilgi odaklı uygulamalar, hava durumu ve iletişim bilgilerinin, havaalanı haritalarının ve havalimanı salonlarının yerleştirilmesinin sağlanmasından farklıdır. Uçuşla ilgili bilgi uygulamaları genellikle uçuş durumu güncellemeleri, görüş programları ve güzergahlar sunar. Aksine, süreç odaklı uygulamalar, rezervasyonları değiştirme, bilet satın alma ya da bir uçuş için check-in yapma gibi mevcut iş süreçlerini harekete geçirmeye odaklanmaktadır. 
Tablo 1 Amerika Havayollarında Mobil Uygulamaların Genel Görünümü

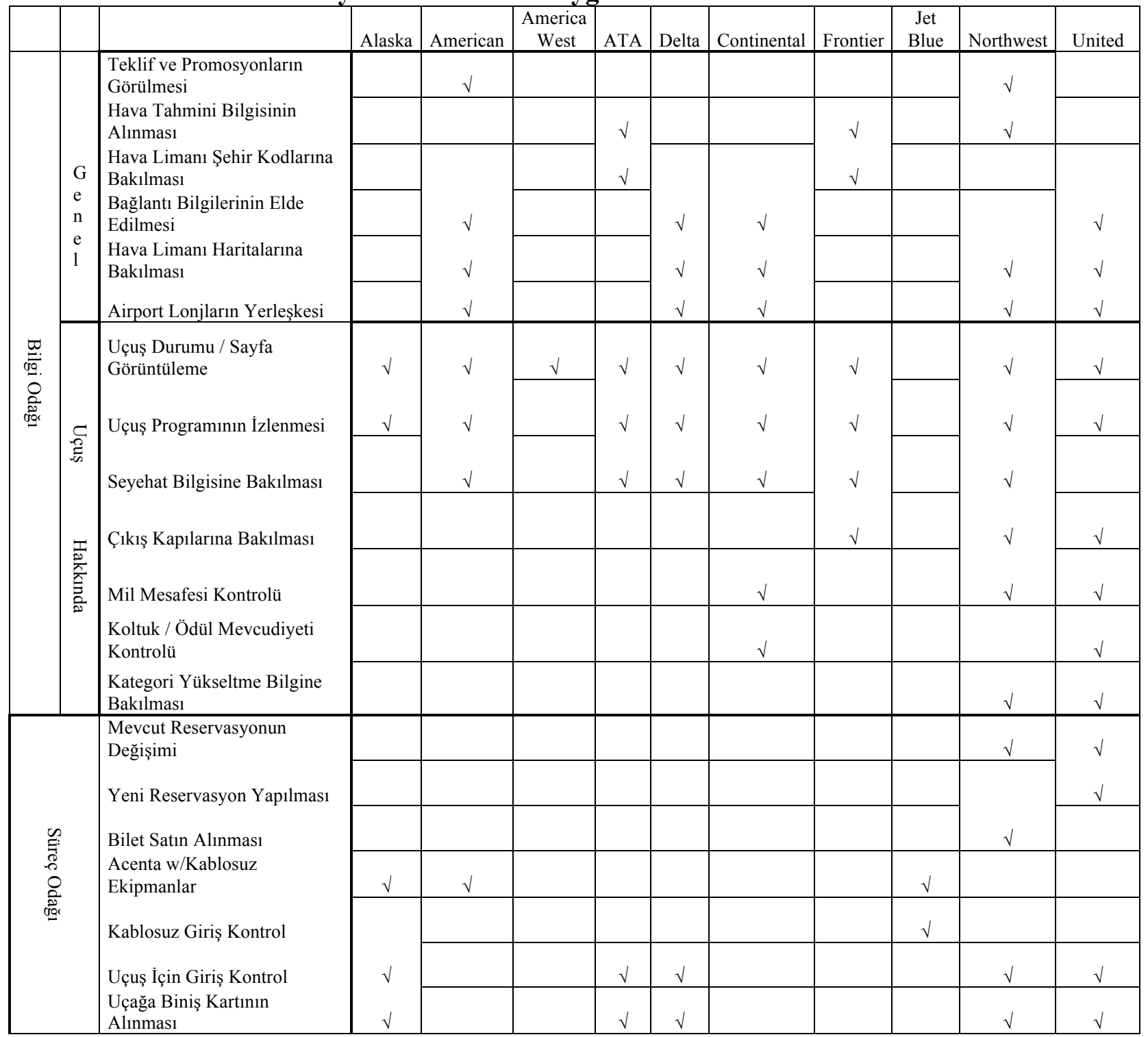

Kaynak: Pagiavlas ve Diğ., 2005, "Mobile Business - A Case Study of the US Airline Industry".

Mobil teknoloji, seyahat yaşam döngüsünün tüm aşamalarını etkilemiştir. Gelişmiş kablosuz ağlarda, web özellikli tam özellikli telefonların, akıllı telefonların ve tabletlerin dünya çapında benimsenmesiyle, yolcular artık bir masaüstü bilgisayarına bağlı değiller, ancak artık her yerden, her zaman birden fazla cihazdan bilgiye anında erişebilmektedirler (www.amadeus.com/web/binaries, 2018). Şekil 1'de gösterildiği üere, mobil teknoloji, havayolu şirketlerine seyahat yaşam döngüsü boyunca sürekli katılım için adeta bir firsat sunmaktadır. 


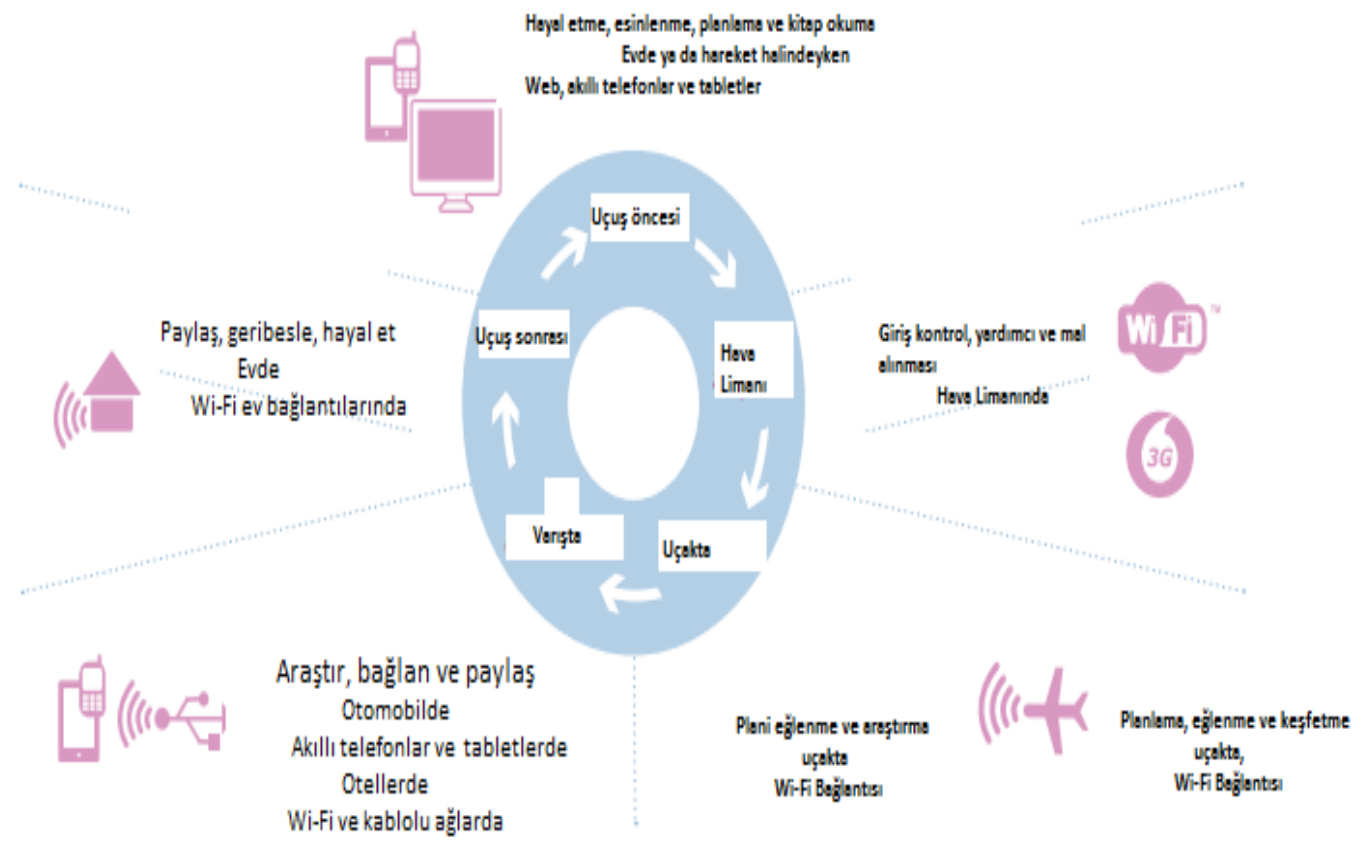

\section{Şekil 1 Mobil Cihazların Çeşitli Cihazlardaki Seyahat Ömrü Boyunca Etkisi}

Kaynak: (www.Amadeus.com, 2018), "How mobile will transform the future of air travel".

Bir yerden bir başka yere seyahat etme sahasında faaliyet gösteren, dünyanın en büyük seyahat sitesilerinde biri de Tripadvisor' dur. Tripadvisor markalı siteler alanında aylık 280 milyonu aşan ziyaretçisi ile 170 milyonu aşan yorum ve görüş ve 4 milyondan fazla otel restoran ve diğer turistik işletmeler ile dünyanın en büyük seyahat topluluğunu oluşturmaktadır (www.tripadvisor.com, 2018). Tripadvisor mobil pazarlamaya yönelik bir çok uygulama gerçekleştirmektedir. Yapılan incelemlerde mobil cihaz kullanıcılarının \%60'ının seyahat uygulamalarını yüklediği ve bu kişilerin $\% 45$ 'inin bilgi almak ya da tur planlamak için bu uygulamalardan yararlandığ bulgusuna ulaşılmaktadır (Mickaiel, 2011). Açıkçası mobil teknoloji seyahat sürecinin her aşamasını etkilemektedir JD power şirketi havayolu ile seyahat edenlerle bugün ve yarın için mobil teknolojilerden ne bekledikerini belirlemeye yönelik yaptığı araştırmada şunları tespit etti (www.amedeus.com, 2018) yolcuların \%39,9'u uçuş durumu ile ilgili anlık durum bilgisi talep etmekte, \%36,6'sı bagajının ulaştığını mobil cihazından görebilmek istiyor, \%39,3 seyahat takvimi bilgisini görmek, \%36,3 uçakta mobil uygulamaları kullanabilmek, \%35,5'si kap1 bilgileri gibi mobilden yönlendirmeler almak, \%31,7'si mobil uçuş giriş kontrol ve rezervasyon, \%31,4'ü kişisel bagaj etiketlemesi yapmak, \%28,5'i ilave hizmetler için peşin ödemeyi, \%26,6's1 dinamik sık uçan programı profiline ulaşmak, \%8,1 karbondioksit vergisi hesaplamayı görmek, \%20,1'i ilave hizmet almak için havalimanı kiosklarına erişim talep etmekte olduğu belirlenmiştir. Ülkemizde özellike tarifeli havayolları olmak üzere (Türk Hava Yolları ve buna bağlı Anadolu Jet, Pegasus, Atlas Global, Sun-Express, Onur Air) tüm hava yolları belirli seviyelerde mobil pazarlama uygulmalarına geçmiş ve bunları 
yakından takip etmektedir. Türk Havayolları da mobil pazarlamayı sürekli kullanmaya çalışan ve gelişimlere ayak uyduran bir kurum olup, Türkiye'de Passbook mobil yönetmini uygulayan ilk Türk şirketi olmuştur. Passbook uygulaması yoluyla uçağa biniş kartları, sinema biletleri ve hediye kartları gibi bilgileri tek bir yerde depolayan yeni bir çalışmadır (IOS Passbook, 2014). Yine "Düşük tarifeli»" havayolu şirketi Pegasus Havayolları mobil cihazlara yatırımı artırarak endüstri ortalamasından \%20 daha yüksek mobil tıklama oranı elde ettiği belirtilerek şirketin bir yıl içinde mobil cihazlarda yapılan marka sorgularını \%61 oranında artırdığı, mobil pazarlama stratejileri ve teknik gelişmeler sayesinde, mobil kanaldan gelen çevrimiçi satışların payı yıllık \%90 artış göstererek hava yolu şirketinin çevrimiçi ve çevrimdışı tüm satış kanalları arasında en büyük üçüncü katkı sağlayıcı haline geldiği belirtilmektedir (www.hypeistanbul.com/pegasus-case-study, 2018). Böylelikle mobil pazarlama ve uygulamalarının havayolu sektöründe giderek yoğunlaşacağı düşünülmektedir.Yolcular artık havalimanı çıkışlarında taksi beklemek istememekte olup, Uber taksi hizmeti mobil uygulama yoluyla hizmetteki bu açığı gidermekte faydanılan bir uygulama olmuştur. Tüketici davranışları; kişisel, sosyal, kültürel, psikolojik, fizyolojik nitelikleri barındırmaktadır (Papatya, 2005, s. 226). Literatürde tüketici davranışları ile ilgili bazı çalışmalar incelendiğinde; Tekvar (2016), "Tüketici Davranışlarının Demografik Özelliklere Göre Tanımlanması" calışmasında, literatür incelemesi yaparak tüketici davranışları demografik çatı altında tanımlanmaya calışılmıştır. Edison'un (Edison'dan aktaran Darban ve Li, 2012, s. 19). Tüketici davranışına açıklık getirmeyi amaçlayan modellerin hemen hemen tümünde ister davranışsal olan göstergeleri, ister davranışsal olmayan göstergeleri ele alsınlar, algılama faktörüne yer vermişlerdir. Algılamanın tüketici davranışı kuramında olduğu kadar, onun bir üst kuramı olan genel pazarlama kuramında da uygulamaya dönük bir katkısı vardır. Bu sebeplerden dolayı havayolu yolcularının hizmet sürecinin her alanında mobil teknolojileri daha fazla kullanma ve bunlardan yararlanma talebi dikkate alındığında seyahat eden yolcuların demografik özellikleri yönünden mobil pazarlama algısının değişip değişmediğinin incelenmesi araştırmaya değer görülerek bu çalışmanın yapılmasına karar verilmiştir. 


\section{Tasarım ve Yöntem}

\subsection{Araştırmanın Modeli ve Hipotezler}

Konuya yönelik araştırma modeli Şekil 1'de belitilmiştir.

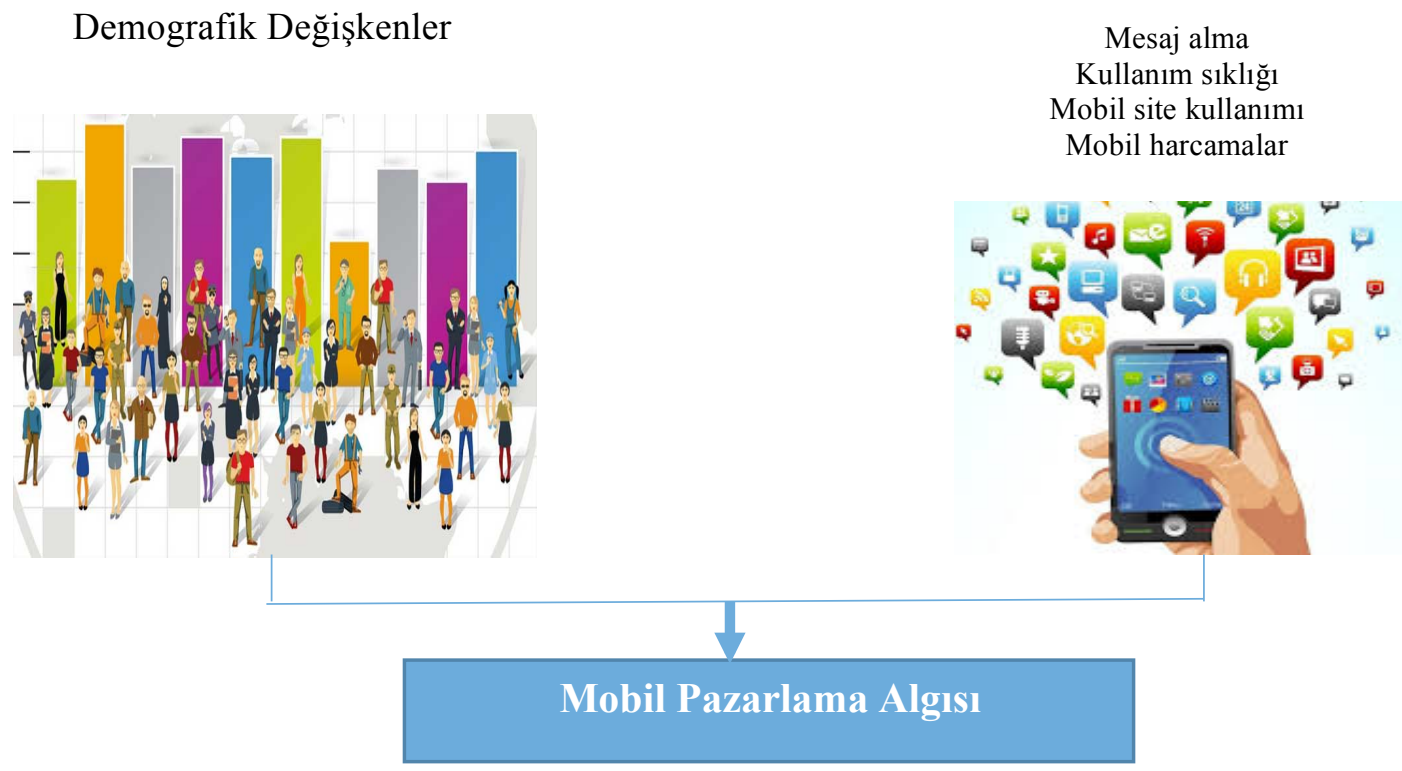

Şekil 1. Araştırmanın Modeli

Yukarıda yer alan açıklamaların doğrultusunda araştırmanın hipotezleri aşağıdaki biçimde kurulmuştur:

a. $\mathrm{H}_{1}$ : Cinsiyete göre havayolu müşterilerinin mobil pazarlama algıları değişmektedir.

b. $\mathrm{H}_{2}$ : Medeni duruma göre havayolu müşterilerinin mobil pazarlama algıları değişmektedir.

c. $\mathrm{H}_{3}$ : Yaşa göre havayolu müşterilerinin mobil pazarlama algıları değişmektedir.

d. $\mathrm{H}_{4}$ : Eğitim seviyesine göre havayolu müşterilerinin mobil pazarlama algıları değișmektedir.

e. $\mathrm{H}_{5}$ : Aylık ortalama gelir seviyesine göre havayolu müşterilerinin mobil pazarlama algıları değişmektedir.

f. $\mathrm{H}_{6}$ : Gelen mobil pazarlama mesajların sıklığına göre havayolu yolcu ve müşterilerinin mobil pazarlama algıları değişmektedir.

g. Müşterilerin demografik özellikleriyle mobil pazarlama mesajları alma, kullanım sıklığı, mobil sitelerden satın alma miktarları ve mobil harcamları yönünden pozitif ve anlamlı ilişkileri vardır.

\subsection{Evren ve Örneklem}

Araştırma, İstanbul Sabiha Gökçen Hava Limanı yolcu çıkış alanında kolayda örnekleme yöntemine bağlı olarak yolcularla yüz yüze anket yönetimine dayalı olarak gerçekleştirilmiştir. Yolculara öncelikle hazırlık sorusu olarak daha önceden havayollarından dijital ortamda bilet satın alıp almadığ 1 ve uçuş yapıp yapmadığı sorulmuş olup eğer yolcu her iki soruya da evet cevabı verdiyse söz konusu ankete devam edilmiş, hayır cevabı alındıysa söz konusu anket değerlendirmeye alınmayarak başka yolcuya geçilmiştir. Ankete katılan 439 havayolu yolcusu arasından 400 tanesi çalışma için uygun olarak değerlendirilerek \%95 güven aralığında örneklem sayısı 
yeterli kabul edilmiştir (Saunders, 2011). Saha araştırma öncesi 12 kişiyle pilot uygulama gerçekleştirilerek soruların anlaşılıp anlaşılamadığı test edilmiş ve soru listesinde varsa eksiklikler giderildikten sonra saha da uygulamaya geçilmiştir.

\subsection{Veri Toplama Yöntemi ve Kullanılan Ölçme Aracı}

Mobil pazarlama ölçeği için Alkaya'nın (2007) çalışmasından alınan beş ifadeli ölçek kullanılmıştır. Toplanan veriler öncelikle ölçekler bazında SPSS paket programından faydalanılarak açıklayıcı faktör ve güvenirlik analizlerine tutularak istatiksel olarak anlamlılık göstermeyen sorular ölçeklerden çıkarılarak ölçekler çalışılabilir hazır hale getirilmişlerdir. Yapılan çalışmada 5'li Likert tipi ölçek kullanılmıştır. Ölçekde (1=kesinlikle katılmıyorum ve 5= kesinlikle katılıyorumu) ifade eden yargılara yer verilmiştir.

\section{Bulgular ve Tartışma}

\subsection{Normalik Testleri}

Yapılan analizde çalışmada kullanılan verilerin normal dağılım gösterdiği belirlenmiştir.

\subsection{Tanımsal İstatistikler}

Tüketicilerin cinsiyet, yaş, medeni durum, aylık ortalama gelir, eğitim durumu ve mesleği ifade eden demografik değişkenlere yönelik demografik istatistikleri aşağıda Tablo 1'de gösterilmiştir.

Tablo 2 Demografik Özellikler

\begin{tabular}{|c|c|c|c|c|c|}
\hline Demografik Özellikler & Frekans & Yüzde & Demografik Özellikler & Frekans & Yüzde \\
\hline Cinsiyet & & & Medeni Durumu & & \\
\hline Kadın & 145 & 36,5 & Evli & 190 & 47,5 \\
\hline \multirow[t]{2}{*}{ Erkek } & 254 & 63,5 & Bekar & 151 & 37,8 \\
\hline & & & Dul & 59 & 14,7 \\
\hline Toplam & 400 & 100 & Toplam & 400 & 400 \\
\hline Yaş & Frekans & Yüzde & Aylık Ort. Gelir & Frekans & Yüzde \\
\hline $18-25$ & 71 & 17,8 & $500-2500 \mathrm{tl}$ & 57 & 14,2 \\
\hline $26-36$ & 132 & 33,0 & $2501-5000 \mathrm{tl}$ & 131 & 32,8 \\
\hline $37-45$ & 133 & 33,3 & $5001-10000 \mathrm{tl}$ & 127 & 31,8 \\
\hline $46-59$ & 53 & 13,3 & $10001-15000 \mathrm{tl}$ & 49 & 12,3 \\
\hline 60 ve üzeri & 11 & 2,8 & $>15000 \mathrm{tl}$ & 36 & 9,0 \\
\hline Toplam & 400 & 100 & Toplam & 400 & 100,0 \\
\hline Eğitim Durumu & Frekans & Yüzde & & & \\
\hline İlkokul mezunu & 15 & 3,8 & & & \\
\hline Orta okul mezunu & 20 & 5,0 & & & \\
\hline Lise mezunu & 97 & 24,3 & & & \\
\hline $\begin{array}{l}\text { Yüksek okul/üniversite } \\
\text { mezunu }\end{array}$ & 233 & 58,3 & & & \\
\hline $\begin{array}{l}\text { Yüksek lisans/ doktora } \\
\text { mezunu }\end{array}$ & 35 & 8,8 & & & \\
\hline Toplam & 400 & 100 & & & \\
\hline
\end{tabular}

Tablo 2'ye bakıldığında tüketicileirn çoğunluğun erkek (\%63), evli (\%48), gençlerden oluşan (\%47 18-36 yaş), alt üst ve orta gelir grubuna sahip (\%64) yüksek eğitimli (\%82) lise ve üzeri kişilerden oluşmaktadır. 


\subsubsection{Mobil Pazarlama İle İlgili Tanımsal İstatistikler}

a. Hangi sıklıkta mobil pazarlama mesajı alındığına ait istatistikler Tablo 3'de gösterilmektedir.

Tablo 3 Mesaj Alma Sıklığı

\begin{tabular}{|l|l|c|c|}
\hline Mesaj S1klı̆̆ 1 & Frekans & Yüzde \\
\hline Geçerli & Her Gün & 92 & 23,0 \\
& Haftada 2-3 Defa & 160 & 40,0 \\
& Haftada 1 Kez & 71 & 17,8 \\
& 2 Haftada 1 Defa & 22 & 5,5 \\
& Ayda 1 Defa & 26 & 6,5 \\
& Bir Kaç Ayda 1 Kez & 29 & 7,2 \\
& Toplam & $\mathbf{4 0 0}$ & $\mathbf{1 0 0 , 0}$ \\
\hline
\end{tabular}

Tablo 3'den görüleceği üzere tüketicilerin büyük çoğunluğu \%81'i hafta da en az 1 veya 1 'den fazla mobil pazarlama mesajı almaktadırlar.

b. Cep telefonlarına gelen mobil mesajların sektörel dağılımını Tablo 4'de yer almaktadır.

Tablo 4 Mesajların Sektörel Dağılımı

\begin{tabular}{|l|l|c|c|}
\hline \multicolumn{2}{|c|}{ Sektör } & Frekans & Yüzde \\
\hline Geçerli & Havac1lı & 72 & 18,0 \\
& Tekstil & 114 & 28,5 \\
& Bankacılık & 147 & 36,8 \\
& Otomotiv & 18 & 4,5 \\
& Gida & 27 & 6,8 \\
& Turizm & 22 & 5,5 \\
& Toplam & 400 & 100,0 \\
\hline
\end{tabular}

Tablo 4'e baktığımızda en çok bankacılık (\%37) ve daha sonra tekstil (\%29) sektörü faaliyetlerine yönelik mesaj gelmekte havacıllk sektörüne yönelik faaliyetlere yönelik ise \%18 ile üçüncü sırada mesajlar gelmektedir.

c. Günde ortalama ne kadar süre internette harcandığı Tablo 5'de görülmektedir.

Tablo 5 Internette Harcanan Günlük Ortalama Süre

\begin{tabular}{|l|l|c|c|}
\hline \multicolumn{2}{|c|}{ Süre } & Frekans & Yüzde \\
\hline Geçerli & $1-3$ saat & 174 & 43,5 \\
& $4-6$ saat & 160 & 40,0 \\
& 7-9 saat & 51 & 12,8 \\
& 10 saat ve üzeri & 14 & 3,5 \\
& 11 & 1 &, 3 \\
& Toplam & 400 & 100,0 \\
\hline
\end{tabular}


Tablo 5'de görüleceği üzere tüketicilerin \%44'lük bir kısmı günde en az 1-3 saat arası vakitlerini internet üzerinde geçirmekte, \%40'1 ise ortalama 4-6 saat aras1 vakitlerini internette geçirdiklerini ifade etmişlerdirki bu oldukça yükse bir rakamdır.

d. Son bir yıl içinde internet üzerinden kaç kez alışveriş yapıldı̆̆ 1 bilgileri Tablo 6 da yer almaktadir.

Tablo 6 Mobil Siteler Üzerinde Alış Veriş Sayısı

\begin{tabular}{|l|l|c|c|}
\hline \multicolumn{2}{|l|}{ Alış veriş sayısı } & Frekans & Yüzde \\
\hline Geçerli & $1-5 \mathrm{kez}$ & 131 & 32,8 \\
& $6-10 \mathrm{kez}$ & 149 & 37,3 \\
& $11-15 \mathrm{kez}$ & 80 & 20,0 \\
& 16 ve üzeri & 40 & 10,0 \\
& Toplam & 400 & 100,0 \\
\hline
\end{tabular}

Tablo 6'da görüldüğü üzere yıl içersinde en çok 6-10 kez (\%37), 1-5 kez (\%33) alış veriş yapıldığg görüldü.

e. Son bir yıl içinde mobil siteler üzerinde yapılan alışverişlerde ortalama haracanan para miktarı Tablo 7'de gösterilmektedir.

Tablo 7 Mobil Siteler Üzerinden Yapılan Harcamalar

\begin{tabular}{|l|l|c|c|}
\hline Aylık Gelir & Frekans & Yüzde \\
\hline Geçerli & $1-1000 \mathrm{tl}$ & 93 & 23,3 \\
& $1001-5000 \mathrm{tl}$ & 167 & 41,8 \\
& $5001-10000 \mathrm{tl}$ & 97 & 24,3 \\
& $10001 \mathrm{tl}$ ve üzeri & 42 & 10,5 \\
\cline { 2 - 4 } & Total & 400 & 100,0 \\
\hline
\end{tabular}

Tablo 7'de görüldüğü üzere en çok önce (\%42)1000-5000 tl aras1 daha sonra 5001-10000 tl arası harcama yapıldı ğı görülmektedir.

\subsection{Açıklayıcı Faktör, Güvenirlik Analizleri Sonuçları}

Seçilen mobil pazarlama ölçeğinin araştırmaya yönelik kullanımı açısından uygunluğunun değerlendirmesi ve faktör boyutlarının belirlenmesine yönelik yapılan faktör ve güvenirlik analiz sonuçları Tablo 8 ve 9' da gösterilmektedir. 
Tablo 8 Faktör Analizi

\begin{tabular}{|c|c|c|c|c|c|}
\hline İfadeler & 1 & 2 & 3 & 4 & $\begin{array}{l}\text { Açıklanan } \\
\text { Varyans \% }\end{array}$ \\
\hline Mobil Pazarlamanın Satın Alma Kararına Etkisi & & & & & 35,6 \\
\hline $\begin{array}{l}\text { Havayollarının mobil pazarlama mesajlarının satın alma kararımı etkiliyen } \\
\text { bilgiler içerdiğini düşünüyorum }\end{array}$ & ,905 & & & & \\
\hline $\begin{array}{l}\text { Havayollarının mobil pazarlama uygulamaları, pazarlama uygulamaları satın } \\
\text { alam kararlarını etkiler }\end{array}$ & 857 & & & & \\
\hline $\begin{array}{l}\text { Havayollarının mobil pazarlama uygulamalarının bana her yerde } \\
\text { ulaşabildiğini düşünüyorum }\end{array}$ & ,607 & & & & \\
\hline Kişisel İzin ve Memnuniyet Algısı & & & & & 13,8 \\
\hline $\begin{array}{l}\text { Havayollarının mobil pazarlama uygulamalarında tüketicinin verdiği iznin } \\
\text { kötüye kullanıldığını düşünüyorum }\end{array}$ & & ,895 & & & \\
\hline $\begin{array}{l}\text { Havayollarının mobil pazarlama uygulamalarından genel olarak memnun } \\
\text { değilim }\end{array}$ & & ,763 & & & \\
\hline Mobil Pazarlama Faaliyetlerine Genel Bakış & & & & & 10,2 \\
\hline $\begin{array}{l}\text { Havayolarında mobil pazarlama yapan firmanın iyi bir itibarı olması } \\
\text { reklama duyduğum güvenini artırır }\end{array}$ & & & & 823 & \\
\hline $\begin{array}{l}\text { Havayollarının mobil pazarlama faaliyetleri geleneksel pazarlama } \\
\text { faaliyetlerinden daha önemlidir }\end{array}$ & & & & ,728 & \\
\hline $\begin{array}{l}\text { Havayollarının mobil pazarlama ve uygulamalarının gelişimi } \\
\text { konusunda olumlu düşüncelere sahibim }\end{array}$ & & & & ,678 & \\
\hline Mobil Pazarlamaya Yönelik İlgilenim & & & & & 9,2 \\
\hline \multicolumn{6}{|l|}{ Havayollarının mobil pazarlama uygulamalarını almaktan rahatsızlık duymam } \\
\hline \multicolumn{6}{|l|}{ Havayollarının mobil pazarlamam mesajlarını daha çok dikkate alırım } \\
\hline \multicolumn{6}{|l|}{ Havacılıkta mobil pazarlama yapan markaya yönelik ilgim artar } \\
\hline Toplam Açıklanan Varyans \% & & & & & 68,9 \\
\hline
\end{tabular}

Yapılan faktör analizi sonucunda KMO değeri 0,77; yine faktör analizi için değişkenler arasında yeterli ilişkinin varlığını gösteren Barlett's testi sonucu 0,00 gerçekleşmiş olup $\mathrm{p}<.001$ düzeyinde anlamlı olduğu görülmektedir. Faktör analizi sonucunda ilgili ölçekten 4 soru çıkarılmıştır. Mobil pazarlama ölçeği 4 boyutla izah edilecek şekilde toplam varyansın \%69'unu açıklayacak seviyeye gelmiştir. Bu kapsamda 1 numaralı boyut mobil pazarlamanın satınalma kararlarına etkisi, 2 numaralı boyut kişisel izin ve memnuniyet algısı, 3 numaralı boyut mobil pazarlama faaliyetlerine genel bakış ve 4 numaralı boyut mobil pazarlama uygulamalarına yönelik 
tutum olarak adlandırılmıştır. Tablo 8'de faktör analizi ile ayrışan üç ölçeğe ait boyutların ortalaması, standart sapması ve Cronbach's Alpha katsayıları verilmiştir.

Tablo 9 Ölçek Boyutlarına Yönelik Ortalama, Standart Sapma ve Cronbach's Alpha

\begin{tabular}{|l|c|c|c|}
\hline Faktörler & Ortalama & $\begin{array}{l}\text { Standart } \\
\text { Sapma }\end{array}$ & Cronbach's Alpha \\
\hline $\begin{array}{l}\text { Mobil Pazarlamanın Satın Alma Kararına } \\
\text { Etkisi }\end{array}$ & 3,7 & 1,2 & 0,76 \\
\hline Kişisel İzin ve Memnuniyet Algısı & 2,7 & 1,1 & 0,58 \\
\hline Mobil Pazarlama Faaliyetlerine Genel Bakış & 3,54 & 1,04 & 0,69 \\
\hline Mobil Pazarlamaya Yönelik İlgilenim & 3,5 & 1,2 & 0,78 \\
\hline
\end{tabular}

Mobil pazarlama ölçeğinde yüzdesel değer üzerinden en çok mobil pazarlama satın alma kararlarına etkisi (\%74), mobil pazarlama faaliyetlerine genel bakış (\%7), mobil pazarlamaya yönelik tutum (\%70) olarak yer almış kişisel izin ve memnuniyet algısı da (\%54) oarak en düşük düzeyde gerçekleşmiştir.

\subsection{Hipotez Testleri ve Korrelasyon Analizi}

Demografik değilkenlere göre araştırmada 20 hipotezin değeri \%95 anlamlılık derecesinde 0,05 'ten büyük olduğu için farklılık söz konusu değil, farklılık gösteren hipotezler değerlendirmeye alınmıştır.

a. Cinsiyete göre havayolu yolcu ve müșterilerinin mobil pazarlama algıları değişmektedir.

Tablo 10 Cinsiyete Göre Boyutların Ortalama Değerleri

\begin{tabular}{|l|l|c|c|c|}
\hline & Cinsiyet & Örneklem & Ortalama & Standart Sapma \\
\hline MP1 & Erkek & 255 & 3,37 & 1,09 \\
& Kadın & 145 & 3,39 & 1,02 \\
\hline MP2 & Erkek & 255 & 2,72 &, 91 \\
& Kadın & 145 & 2,56 &, 93 \\
\hline \multirow{2}{*}{ MP3 } & Erkek & 255 & 3,49 &, 81 \\
& Kadın & 145 & 3,63 &, 86 \\
\hline \multirow{2}{*}{ MP4 } & Erkek & 255 & 3,42 & 1,03 \\
& Kadın & 145 & 3,65 &, 95 \\
\hline
\end{tabular}

Tablo 11 Cinsiyete Göre "t" Testi

\begin{tabular}{|l|c|c|c|c|c|c|}
\hline Hipotez/Değişken & $\mathbf{n}$ & Ortalama & $\begin{array}{c}\text { Standart } \\
\text { Sapma }\end{array}$ & df & t & p \\
\hline $\begin{array}{l}\text { Mobil Pazarlamaya Yönelik } \\
\text { İlgilenim }\end{array}$ & 400 & 3,65 & 1,821 & 398 & $-2,217$ &, 027 \\
\hline
\end{tabular}


Yapılan bağımısız " $\mathrm{t}$ " testi analize göre sadece mobil pazarlamaya yönelik tutum boyutunda katılımcıların cinsiyetlerine göre nin \%95 güven seviyesinde anlamlılık gösterdiği $(\mathrm{p}=0,027<0,05)$ görülmüştür. Yapılan incelemede kadın $\mathrm{n}$ tüketicilerde mobil pazarlamaya yönelik ilgileninimin erkeklere göre daha yüksek olduğu tespit edilmiş olup ilgili $\mathrm{H}_{1}$ hipotezi sadece bu boyutta kabul edilmiştir.

b. Medeni durumuna göre havayolu yolcu ve müşterilerin mobil pazarlama algıları değişmektedir.

Yapılan tek yönlü varyans analizi neticesine göre boyutlardaki istatiksel anlamlılık değerleri sırasıyla; $(p=0,40 ; 0,25 ; 0,53 ; 0,48)$ olarak belirlenmiş olup \%95 güven aralığında bu anlamlılık değerleri 0,05 'den büyük oldukları için ilgili $\mathrm{H}_{2}$ hipotezi ret edilerek medeni duruma göre havayolu yolcu ve müşterilerin mobil pazarlama algılarının değişmediği belirlenmiştir.

c. Yaş seviyesine göre havayolu yolcu ve müşterilerin mobil pazarlama algıları değişmektedir.

Yaş gruplarına yönelik yapılan tek yönlü varyans analizi sonuçlarına göre mobil pazarlama boyutlarında istatiksel anlamlılık değerleri sırasıyla; $(p=0,54 ; 0,06$; $0,11 ; 0,76)$ olarak belirlenmiş olup \%95 güven aralığında bu anlamlılık değerleri 0,05 'den büyük oldukları için ilgili $\mathrm{H}_{3}$ hipotezi ret edilerek medeni duruma göre havayolu yolcu ve müşterilerin mobil pazarlama algılarının değişmediği belirlenmiştir.

d. Eğitim seviyesine göre havayolu yolcu ve müşterilerin mobil pazarlama algıları değişmektedir.

Tablo 12 Eğitim Seviyesine Göre Yapılan Tek Yönlü Varyans Analizi Sonuçları

\begin{tabular}{|c|c|c|c|c|c|c|c|}
\hline Boyut & $\begin{array}{l}\text { Eğitim } \\
\text { Grubu }\end{array}$ & $\mathrm{n}$ & Ortalama & $\begin{array}{l}\text { Standart } \\
\text { Sapma }\end{array}$ & $\mathrm{F}$ & $\mathrm{P}$ & $\begin{array}{l}\text { Anlamlı } \\
\text { Fark }\end{array}$ \\
\hline \multirow{5}{*}{$\begin{array}{l}\text { Mobil } \\
\text { pazarlamanın } \\
\text { satın alma } \\
\text { kararlarına } \\
\text { etkisi }\end{array}$} & ilkokul & 15 & 2,3 & 1,037 & 4,912 & 0,01 & \\
\hline & ortaokul & 20 & 3,03 & 1,159 & & & \\
\hline & lise & 97 & 3,31 & 1,13 & & & (ilkokul - lise) \\
\hline & $\begin{array}{l}\text { yüksekokul/ } \\
\text { üniversite }\end{array}$ & 233 & 3,46 & 1,0 & & & $\begin{array}{l}\text { (ilkokul - yüksek } \\
\text { okul / üniversite) }\end{array}$ \\
\hline & $\begin{array}{l}\text { yüksek lisans / } \\
\text { doktora }\end{array}$ & 35 & 3,60 & 98 & & & $\begin{array}{l}\text { (ilkokul - yüksek } \\
\text { lisans / doktora }\end{array}$ \\
\hline \multirow{4}{*}{$\begin{array}{l}\text { Kişisel İzin ve } \\
\text { Memnuniyet } \\
\text { Algısı }\end{array}$} & ilkokul & 15 & 2,80 & ,92 & 5,946 & 0,00 & \\
\hline & ortaokul & 20 & 3,20 & ,92 & & & \\
\hline & lise & 97 & 2,89 & 99 & & & $\begin{array}{c}\text { (lise - yüksek okul / } \\
\text { üniversite) }\end{array}$ \\
\hline & yüksekokul/ & 233 & 2,48 & ,85 & & & $\begin{array}{c}\text { (orta okul - } \\
\text { yüksek okul / }\end{array}$ \\
\hline
\end{tabular}




\begin{tabular}{|c|c|c|c|c|c|c|c|}
\hline & üniversite & & & & & & universite) \\
\hline & $\begin{array}{l}\text { yüksek lisans / } \\
\text { doktora }\end{array}$ & 35 & 2,84 & 92 & & & \\
\hline \multirow{6}{*}{$\begin{array}{l}\text { Mobil } \\
\text { Pazarlama } \\
\text { Faaliyetlerine } \\
\text { Genel Bakış }\end{array}$} & ilkokul & 15 & 3,15 & ,74 & 5,276 & 0,00 & \\
\hline & ortagkul & 20 & 205 & 115 & & & \\
\hline & & & & & & & \\
\hline & lise & 97 & 3,57 & ,90 & & & (orta okul- lise) \\
\hline & $\begin{array}{l}\text { yüksekokul/ } \\
\text { üniversite }\end{array}$ & 233 & 3,65 & ,75 & & & $\begin{array}{c}\text { (orta okul - yüksek } \\
\text { okul / üniversite) }\end{array}$ \\
\hline & $\begin{array}{l}\text { yüksek lisans / } \\
\text { doktora }\end{array}$ & 35 & 3,30 & 75 & & & \\
\hline \multirow{5}{*}{$\begin{array}{l}\text { Mobil } \\
\text { Pazarlamaya } \\
\text { Yönelik Tutum }\end{array}$} & ilkokul & 15 & 2,73 &, 80 & 3,706 & 0,00 & \\
\hline & ortaokul & 20 & 3,3833 & 1,3 & & & \\
\hline & lise & 97 & 3,6082 & 1,01 & & & (ilkokul - lise) \\
\hline & $\begin{array}{l}\text { yüksekokul/ } \\
\text { üniversite }\end{array}$ & 233 & 3,5729 & ,95 & & & $\begin{array}{l}\text { (İlkokul - yüksek } \\
\text { okul / üniversite) }\end{array}$ \\
\hline & $\begin{array}{l}\text { yüksek lisans / } \\
\text { doktora }\end{array}$ & 35 & 3,1905 & 1,03 & & & \\
\hline
\end{tabular}

Eğitim gruplarına göre yapılan tek yönlü varyans analizinde tüm boyutlarda elde edilen ortalama değerleri, standart sapmaları Tablo 10' da gösterilmekte olup, tüm eğitim faktörü açısından tüm boyutlarda istatiksel olarak anlamlılık tespit eilmiş olup ilgili $\mathrm{H}_{4}$ hipotezi kabul edilmiştir. Mobil pazarlamanın satın alma kararlarına etkisine yönelik Varyans analiz sonucunda $F=4,912,(p=0,01<0,05)$ istatiksel anlamlı farklılık tespit edilmiştir. Farklılığın kaynağını belirlemek için Post Hoc testlerinde Tukey testi kullanılmıştır. Bu sonuçlara göre:

- Lise mezunlarının ilkokul mezunlarına göre mobil pazarlamanın satın alma kararlarında etkisini daha yüksek bulmuşlardır. Aralarındaki ortalama farkı 0,93'dür ve anlamlılık düzeyi 0,001 dir. Farklılığın yönü (lise - ilkokul) şeklinde bulunmuştur.

- Yüksek okul /üniversite mezunlarının ilkokul mezunlarına göre mobil pazarlamanın satın alma kararlarında etkisini daha yüksek bulmuşlardır. Aralarındaki ortalama fark1 1,09'dur ve anlamlılık düzeyi 0,01 dir. Farklılığın yönü (yüksek okul / üniversite - ilkokul) şeklinde bulunmuştur.

- Lisans üstü / doktora mezunlarının ilkokul mezunlarına göre mobil pazarlamanın satın alma kararlarında etkisini daha yüksek bulmuşlardır. Aralarındaki ortalama fark1 1,23'dür ve anlamlılık düzeyi 0,002 dir. Farklılı̆̆ın yönü (yüksek okul / üniversite - ilkokul) şeklinde bulunmuştur. 
Kişisel izin ve memnuniyet algısına yönelik Varyans analiz sonucunda $F$ $=5,946,(p=0,00<0,05)$ istatiksel anlamlı farklılık tespit edilmiştir. Farklılığın kaynağını belirlemek için Post Hoc testlerinde Tukey testi kullanılmıştır. Bu sonuçlara göre :

- Orta okul mezunlarının yüksek okul / üniveriste mezunlarına göre kişisel izin ve memnuniyet algısını daha yüksek bulmuşlardır. Aralarındaki ortalama farkı 0,42'dir ve anlamlılık düzeyi 0,007 dir. Farklılığın yönü (orta okul - yüksek okul / üniveriste) şeklinde bulunmuştur.

- lise mezunlarının yüksek okul / üniveriste mezunlarına göre kişisel izin ve memnuniyet algısını daha yüksek bulmuşlardır. Aralarındaki ortalama farkı 0,71'dir ve anlamlılık düzeyi 0,002 dir. Farklılığın yönü lise - yüksek okul / üniveriste) şeklinde bulunmuştur.

Mobil pazarlama genel faaliyetleri bakışına yönelik Varyans analiz sonucunda $F=5,276,(p=0,00<0,05)$ istatiksel anlamlı farklılık tespit edilmiştir. Farklılığın kaynağını belirlemek için Post Hoc testlerinde Tukey testi kullanılmıştır. Bu sonuçlara göre :

- lise mezunlarının orta okul mezunlarına göre genel pazarlama faaliyetlerine bakış açısnı daha yüksek bulmuşlardır. Aralarındaki ortalama farkı 0,62'dir ve anlamlılık düzeyi 0,016 dır. Farklılığın yönü (lise - orta okul) şeklinde bulunmuştur.

- Yüksek okul / üniversite mezunlarının orta okul mezunlarına göre genel pazarlama faaliyetlerine bakış açısnı daha yüksek bulmuşlardır. Aralarındaki ortalama farkı 0,69'dur ve anlamlılık düzeyi 0,002 dir. Farklılığın yönü (yüksek okul / üniveriste - orta okul) şeklinde bulunmuştur.

Mobil pazarlamaya tutume yönelik Varyans analiz sonucunda $\mathrm{F}=3,706$, $(\mathrm{p}=0,00<0,05)$ istatiksel anlamlı farklılık tespit edilmiştir. Farklılığın kaynağını belirlemek için Post Hoc testlerinde Tukey testi kullanılmıştır. Bu sonuçlara göre :

- lise mezunlarının ilkokul mezunlarına göre genel mobil pazarlamaya yönelik tutumi daha yüksek bulmuşlardır. Aralarındaki ortalama farkı 0,87 'dir ve anlamlılık düzeyi 0,015 dir. Farklılığın yönü (lise - ilkokul) şeklinde bulunmuştur.

- Yüksek okul / üniversite mezunlarının ilkokul mezunlarına göre genel mobil pazarlamaya yönelik tutumi daha yüksek bulmuşlardır. Aralarındaki ortalama farkı 0,83'dür ve anlamlılık düzeyi 0,015 dir. Farklılığın yönü (yüksek okul /üniversite - ilkokul) şeklinde bulunmuştur.

e. Gelir seviyesine göre havayolu yolcu ve müşterilerin mobil pazarlama algıları değişmektedir. 
Tablo 13 Gelir Seviyesine Göre Yapılan Tek Yönlü Varyans Analizi Sonuçları

\begin{tabular}{|c|c|c|c|c|c|c|c|}
\hline Boyut & $\begin{array}{l}\text { Gelir } \\
\text { Grubu }\end{array}$ & $\mathrm{n}$ & Ortalama & $\begin{array}{l}\text { Standart } \\
\text { Sapma }\end{array}$ & $\mathrm{F}$ & $\mathrm{P}$ & $\begin{array}{c}\text { Anlamlı } \\
\text { Fark }\end{array}$ \\
\hline \multirow{5}{*}{$\begin{array}{l}\text { Mobil } \\
\text { pazarlamanın } \\
\text { satın alma } \\
\text { kararlarına } \\
\text { etkisi }\end{array}$} & $500-2500 \mathrm{tl}$ & 57 & 3,07 & 1,17 & 4,240 & 0,00 & $(500-2500)-(>15000)$ \\
\hline & $2501-5000 \mathrm{tl}$ & 131 & 3,37 & ,98 & & & $(2501-5000)-(>15000)$ \\
\hline & $5001-10000 \mathrm{tl}$ & 127 & 3,33 & 1,04 & & & $(5001-1000)-(>15000)$ \\
\hline & $10001-15000 \mathrm{tl}$ & 49 & 3,44 & 1,18 & & & \\
\hline & $>15000 \mathrm{tl}$ & 36 & 3,9815 & ,87267 & & & \\
\hline \multirow{5}{*}{$\begin{array}{l}\text { Kişisel İzin ve } \\
\text { Memnuniyet } \\
\text { Algısı }\end{array}$} & $500-2500 \mathrm{tl}$ & 57 & 2,5439 & ,92 & 1,375 & 0,24 & \\
\hline & $2501-5000 \mathrm{tl}$ & 131 & 2,6870 & ,92 & & & \\
\hline & $5001-10000 \mathrm{tl}$ & 127 & 2,7913 & ,99 & & & \\
\hline & $10001-15000 \mathrm{tl}$ & 49 & 2,5408 & ,85 & & & \\
\hline & $>15000 \mathrm{tl}$ & 36 & 2,5000 & ,92 & & & \\
\hline \multirow{5}{*}{$\begin{array}{l}\text { Mobil } \\
\text { Pazarlama } \\
\text { Faaliyetlerine } \\
\text { Genel Bakış }\end{array}$} & $500-2500 \mathrm{tl}$ & 57 & 3,54 & ,96 & 0,26 & 0,99 & \\
\hline & $2501-5000 \mathrm{tl}$ & 131 & 3,53 & ,74 & & & \\
\hline & $5001-10000 \mathrm{tl}$ & 127 & 3,56 & ,83 & & & \\
\hline & $10001-15000 \mathrm{tl}$ & 49 & 3,56 & ,93 & & & \\
\hline & $>15000 \mathrm{tl}$ & 36 & 3,51 & ,77 & & & \\
\hline \multirow{5}{*}{$\begin{array}{l}\text { Mobil } \\
\text { Pazarlam: } \\
\text { Yönelik } \\
\text { İlgilenim }\end{array}$} & $500-2500 \mathrm{tl}$ & 57 & 3,51 & 1,12 & 0,606 & 0,658 & \\
\hline & $2501-5000 \mathrm{tl}$ & 131 & 3,44 & ,95 & & & \\
\hline & $5001-10000 \mathrm{tl}$ & 127 & 3,48 & ,98 & & & \\
\hline & $10001-15000 \mathrm{tl}$ & 49 & 3,57 & 1,12 & & & \\
\hline & $>15000 \mathrm{tl}$ & 36 & 3,72 & 1,00 & & & \\
\hline
\end{tabular}

Gelir gruplarına göre yapılan tek yönlü varyans analizinde tüm boyutlarda elde edilen ortalama değerleri, standart sapmaları Tablo 11' de gösterilmektedir. Yapılan analizde sadece mobil pazarlamanın satın alma kararlarına etkisine yönelik Varyans analiz sonucunda $F=4,240,(p=0,00<0,05)$ istatiksel anlamlı farklılık tespit edilmiş olup sadece bu boyutta ilgili H5 hipotezi kabul edilmişitir. Farklılığın kaynağını belirlemek için Post Hoc testlerinde Tukey testi kullanılmıştır. Bu sonuçlara göre : 
- Aylık geliri 15.000 ve üzeri olanlar 500-2500 olanlara göre mobil pazarlamanın satın alma kararlarında etkisini daha yüksek bulmuşlardır. Aralarındaki ortalama farkı 0,90 ve anlamlılık düzeyi 0,001 dir. Farklılığın yönü $(>15.000$ - 5002500) şeklinde bulunmuştur.

- Aylık geliri 15.000 ve üzeri olanlar 2500-5000 olanlara göre mobil pazarlamanın satın alma kararlarında etkisini daha yüksek bulmuşlardır. Aralarındaki ortalama fark1 0,60 ve anlamlılık düzeyi 0,018 dir. Farklılı̆̆ın yönü $(>15.000-2500$ 5000) şeklinde bulunmuştur.

- Aylık geliri 15.000 ve üzeri olanlar 5000-10.000 olanlara göre mobil pazarlamanın satın alma kararlarında etkisini daha yüksek bulmuşlardır. Aralarındaki ortalama farkı 0,64 ve anlamlılık düzeyi 0,004 dür. Farklılığın yönü (>15.000 - 5000-10.000) şeklinde bulunmuştur.

f. Mobil mesaj alma sıklığına göre havayolu yolcu ve müşterilerin mobil pazarlama algıları değişmektedir.

Tablo 14 Mesaj Alma Sıklığına Göre Mobil Pazarlama Algısı

\begin{tabular}{|c|c|c|c|c|c|c|c|}
\hline Boyut & $\begin{array}{c}\text { Mobil Mesaj } \\
\text { Grubu }\end{array}$ & $\mathrm{n}$ & Ortalama & $\begin{array}{c}\text { Standart } \\
\text { Sapma }\end{array}$ & $\mathrm{F}$ & $\mathrm{P}$ & $\begin{array}{c}\text { Anlamlı } \\
\text { Fark }\end{array}$ \\
\hline \multirow{6}{*}{$\begin{array}{l}\text { Mobil } \\
\text { pazarlamanın } \\
\text { satın alma } \\
\text { kararlarına } \\
\text { etkisi }\end{array}$} & her gün & 92 & 3,68 & ,99 & 6,107 & 0,00 & ( hergün - ayda 1 defa) \\
\hline & haftada 2-3 defa & 160 & 3,48 & 1,01 & & & \\
\hline & haftada $1 \mathrm{kez}$ & 71 & 3,29 & 1,09 & & & \\
\hline & 2 haftada 1 defa & 22 & 3,15 & 1,17 & & & \\
\hline & ayda 1 defa & 26 & 2,83 & 1,15 & & & \\
\hline & $\begin{array}{l}\text { bir kaç ayda bir } \\
\text { kez }\end{array}$ & 29 & 2,71 & ,92 & & & $\begin{array}{c}\text { ( hergün - bir kaç aya } \\
1 \mathrm{kez}\end{array}$ \\
\hline \multirow{6}{*}{$\begin{array}{l}\text { Kişisel İzin ve } \\
\text { Memnuniyet } \\
\text { Algısı }\end{array}$} & her gün & 92 & 2,65 & 1,0 & 1,298 & 0,26 & \\
\hline & haftada 2-3 defa & 160 & 2,56 & ,88 & & & \\
\hline & haftada $1 \mathrm{kez}$ & 71 & 2,73 & ,95 & & & \\
\hline & 2 haftada 1 defa & 22 & 2,77 & ,96 & & & \\
\hline & ayda 1 defa & 26 & 2,65 & 80 & & & \\
\hline & $\begin{array}{l}\text { bir kaç ayda bir } \\
\text { kez }\end{array}$ & 36 & 2,50 & ,92 & & & \\
\hline \multirow{3}{*}{$\begin{array}{l}\text { Mobil } \\
\text { Pazarlama } \\
\text { Faaliyetlerine } \\
\text { Genel Bakış }\end{array}$} & her gün & 92 & 3,7609 & ,78 & 5,527 & 0,00 & $\begin{array}{c}\text { (hergün }-2 \text { haftada bir } \\
\text { defa) }\end{array}$ \\
\hline & haftada 2-3 defa & 160 & 3,6 & ,71 & & & $\begin{array}{l}\text { (haftada 2-3 defa - } \\
\text { ayda } 1 \text { defa) }\end{array}$ \\
\hline & haftada $1 \mathrm{kez}$ & 71 & 3,4 &, 86 & & & \\
\hline
\end{tabular}




\begin{tabular}{|c|c|c|c|c|c|c|c|}
\hline & 2 haftada 1 defa & 22 & 3,15 & 1,22 & & & \\
\hline & ayda 1 defa & 26 & 3,15 &, 76 & & & $\begin{array}{c}\text { (her gün - ayda bir } \\
\text { defa) }\end{array}$ \\
\hline & $\begin{array}{l}\text { bir kaç ayda bir } \\
\text { kez }\end{array}$ & 29 & 3,21 & ,91 & & & $\begin{array}{c}\text { (her gün - birkaç ayda } \\
1 \mathrm{kez} \text { ) }\end{array}$ \\
\hline \multirow{6}{*}{$\begin{array}{l}\text { Mobil } \\
\text { Pazarlamaya } \\
\text { Yönelik } \\
\text { İlgilenim }\end{array}$} & her gün & 92 & 3,52 & 1,04 & 4,140 & 0,01 & $\begin{array}{c}\text { (her gün }-1 \text { kaç ayda } \\
\text { bir kez) }\end{array}$ \\
\hline & haftada 2-3 defa & 160 & 3,70 & ,89 & & & $\begin{array}{l}\text { (haftada 2-3 defa - } \\
\text { daha seyrek) }\end{array}$ \\
\hline & haftada $1 \mathrm{kez}$ & 71 & 3,44 & 1,01 & & & \\
\hline & 2 haftada 1 defa & 22 & 3,18 & 1,28 & & & \\
\hline & ayda 1 defa & 26 & 3,38 & 1,014 & & & \\
\hline & $\begin{array}{l}\text { bir kaç ayda bir } \\
\text { kez }\end{array}$ & 29 & 2,88 & 1,016 & & & \\
\hline
\end{tabular}

Mesaj alma sıklığına göre yapılan tek yönlü varyans analizinde tüm boyutlarda elde edilen ortalama değerleri, standart sapmaları Tablo 12' de gösterilmekte olup kişisel izin ve memnuniyet algısı boyutu haricinde diğer tüm boyutlarda istatisksel anlamlılık tespit edilmiş olup, ilgili $\mathrm{H}_{6}$ hipotezi bir boyut haricinde diğer üç boyut için kabul edilmektedir. Mobil pazarlamanın satın alma kararlarına etkisine yönelik Varyans analiz sonucunda $F=6,107,(p=0,00<0,05)$ istatiksel anlamlı farklılık tespit edilmiştir. Farklılığın kaynağını belirlemek için Post Hoc testlerinde Tukey testi kullanılmıştır. Bu sonuçlara göre :

- Her gün mesaj alanlar ayda 1 kez alanlara göre mobil pazarlamanın satın alma kararlarında etkisini daha yüksek bulmuşlardır. Aralarındaki ortalama farkı 0,85 ve anlamlılık düzeyi 0,003 dür. Farklılığın yönü (her gün - ayda 1 defa) şeklinde bulunmuştur.

- Her gün mesaj alanlar bir kaç ayda 1 kezden alanlara göre mobil pazarlamanın satın alma kararlarında etkisini daha yüksek bulmuşlardır. Aralarındaki ortalama farkı 0,97 ve anlamlılık düzeyi 0,00 dır. Farklılığın yönü (her gün - birkaç ayda $1 \mathrm{kez}$ ) şeklinde bulunmuştur.

- Haftada 2-3 mesaj alanlar ayda 1 kez alanlara göre mobil pazarlamanın satın alma kararlarında etkisini daha yüksek bulmuşlardır. Aralarındaki ortalama farkı 0,65 ve anlamlılık düzeyi 0,035 dür. Farklılığın yönü (haftada 2-3 alanlar ayda 1 defa) şeklinde bulunmuştur.

- Haftada 2-3 mesaj alanlar birkaç ayda $1 \mathrm{kez}$ alanlara göre mobil pazarlamanın satın alma kararlarında etkisini daha yüksek bulmuşlardır. Aralarındaki ortalama farkı 0,77 ve anlamlılık düzeyi 0,003 dür. Farklılığın yönü (haftada 2-3 alanlar bir kaç ayda $1 \mathrm{kez}$ ) şeklinde bulunmuştur.

Mobil pazarlama genel faaliyetleirine yönelik bakış açısıı için yapılan Varyans analiz sonucunda $F=5,527(\mathrm{p}=0,00<0,05)$ istatiksel anlamlı farklılık tespit edilmiştir. 
Farklılığın kaynağını belirlemek için Post Hoc testlerinde Tukey testi kullanılmıştır. Bu sonuçlara göre:

- Her gün mesaj alanlar 2 haftada 1 kez alanlara göre mobil pazarlamanın faaliyetleri genel bakış açısı etkisini daha yüksek bulmuşlardır. Aralarındaki ortalama farkı 0,60 ve anlamlılık düzeyi 0,02 dir. Farklılığın yönü (her gün - 2 haftada $1 \mathrm{kez}$ ) şeklinde bulunmuştur.

- Her gün mesaj alanlar ayda $1 \mathrm{kez}$ alanlara göre mobil pazarlamanın mobil pazarlamanın faaliyetleri genel bakış açısı etkisini daha yüksek bulmuşlardır. Aralarındaki ortalama farkı 0,60 ve anlamlılık düzeyi 0,01 dir. Farklılığın yönü (her gün- ayda $1 \mathrm{kez}$ ) şeklinde bulunmuştur.

- Her gün mesaj alanlar birkaç ayda 1 kez alanlara göre mobil pazarlamanın mobil pazarlamanın faaliyetleri genel bakış açısı etkisini daha yüksek bulmuşlardır. Aralarındaki ortalama farkı 0,54 ve anlamlılık düzeyi 0,022 dir. Farklılı̆̆ın yönü (her gün - birkaç ayda $1 \mathrm{kez}$ ) şeklinde bulunmuştur.

Mobil pazarlama tutumi için Varyans analiz sonucunda $F=4,140,(p=0,01<0,05)$ istatiksel anlamlı farklılık tespit edilmiştir. Farklılığın kaynağını belirlemek için Post Hoc testlerinde Tukey testi kullanılmıştır. Bu sonuçlara göre :

- Her gün mesaj alanlar birkaç ayda $1 \mathrm{kez}$ alanlara göre mobil pazarlamanın tutum etkisini daha yüksek bulmuşlardır. Aralarındaki ortalama farkı 0,64 ve anlamlılık düzeyi 0,03 dür. Farklılığın yönü (her gün - birkaç ayda $1 \mathrm{kez}$ ) şeklinde bulunmuştur.

- Müşterilerin demografik özellikleriyle mobil pazarlama mesajları alma,kullanım sıklığ 1 , mobil sitelerden satın alma miktarları ve mobil harcamları aralarındaki ilişkileri gösteren korrelasyon katsayıları Tablo 15'de gösterilmiştir.

Tablo 15 Pearson Korrelasyon Analizi

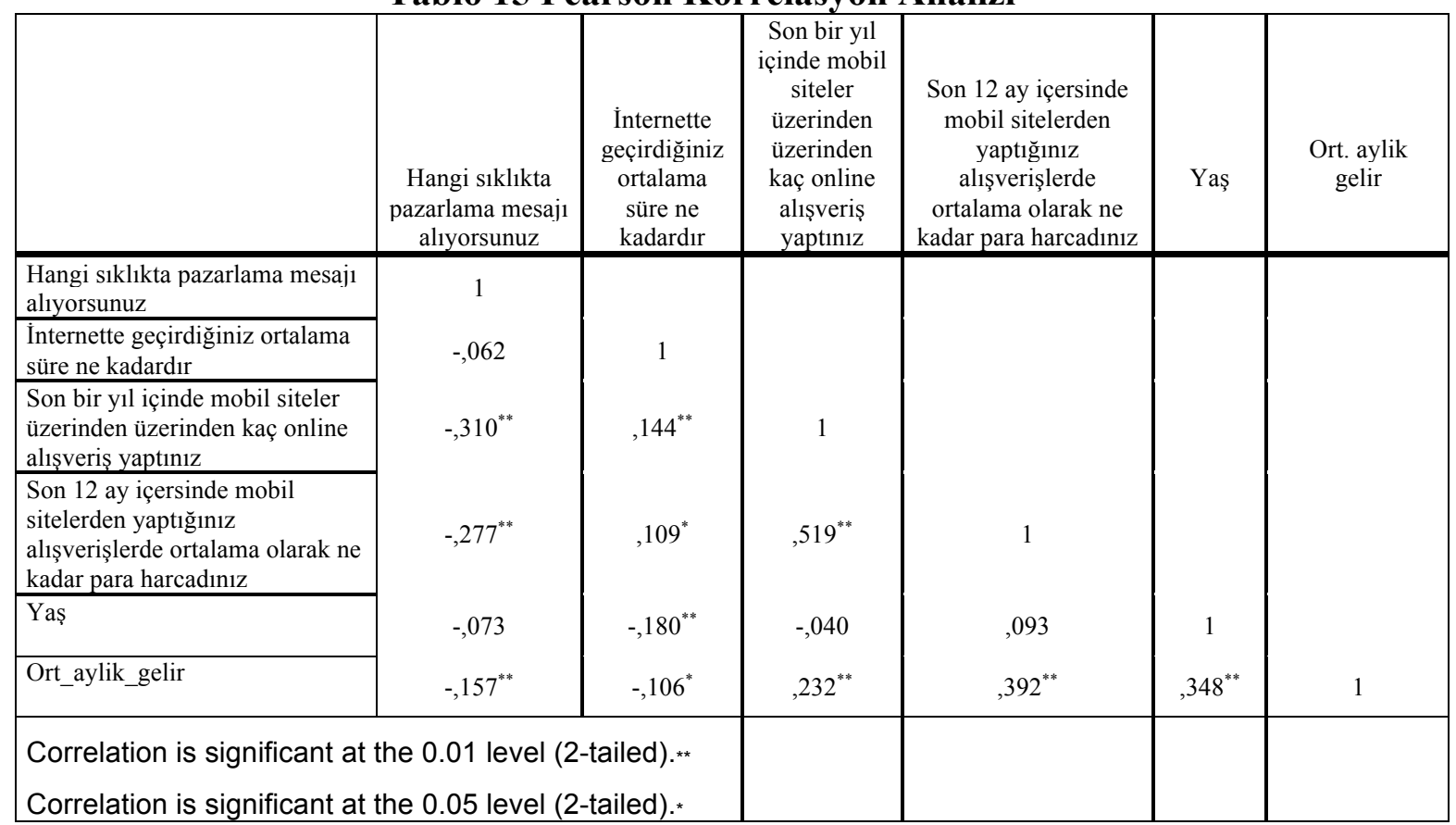


Havayolu müşterilerinin mobil mesaj alma sıklıklarıyla online alışveriş yapma eğilimi arasında $\left(\mathrm{r}=-, 31^{* *}\right)$ negatif yönde anlamlı bir ilişki ortaya cıkmıştır. Müşteriler tarafından yapılan alışveriş miktarı ile bu alışverişte harcanan ortalama para miktarı arasında $\left(\mathrm{r}=, 519^{* *}\right)$ anlamlı ve pozitif yonlu ilişki bulunmuştur. Müşterilerin gelirleri ile yaşları arasında $\left(\mathrm{r}=, 348^{* *}\right)$, yapılan rezervasyonlara harcanan ortalama para miktarıyla müşterilerim geliri arasında da $\left(\mathrm{r}=, 392^{* *}\right)$ anlamlı ve pozitif yönlü ilişki ortaya cıkmıştır. Yapılan alışveriş miktarı ile tuketicilerin internette gecirdiği ortalama süre arasında $(\mathrm{r}=, 144 * *)$ anlamlı ve pozitif yönlü, yapılan alışveriş miktarı ile gelir arasında da $\left(\mathrm{r}=, 232^{* *}\right)$ pozitif ve anlamlı ilişki bulunmuştur. Müşterilerin internette gecirdiği ortalama sure ile yaptığ ,109**) anlamlı ve pozitif yönlü ilişki bulunmuştur.

\section{Sonuç}

Çalışmada, Alkaya'nın geliştirdiği 15 sorulu mobil pazarlama ölçeği kullanıma uygunluk açısından 12 soruya düşürülerek ölçek 4 boyutta havayolu sektörü tüketicilerine yönelik mobil pazarlama algılarını ölçebilir hale getirilmiştir. Mobil pazarlama yoluyla alınan mesajların \%18'i havayolu sektörü olarak ortaya çıktığından bu uygulamaların en yoğun sektörlerden biri olduğu görülmüştür Elde edilen havayolu mobil pazarlama ölçeğine göre tüketcilerin mobil pazarlama algıları; mobil pazarlamanın satın alma kararlarına etkisinde, kişisel izin ve memnuniyet algısında, genel bir bakış olarak mobil pazarlama faaliyetlerinde ve mobil pazarlamaya yönelik tutum alanlarında ortaya çıkarak bunlar gruplandırılarak birer faktör olarak isimlendirilmişlerdir. Tüketicilerin demografik faktörlere göre mobil pazarlama algılarına bakıldığında cinsiyet yönünden sadece mobil pazarlamaya yönelik tutum boyutunda anlamlı bir farklılık olduğu görülmüş olup kadınlarda mobil pazarlamaya yönelik tutumlarının olumlu yönde daha fazla arttığı görülmüştür. Yaş ve medeni durum açısından istatiksel olarak anlamlı bir fark görülmese de tüketiclerin eğitim durumları yönünden mobil pazarlamanın tüm boyutlarında istatiksel olarak anlamlı farklılıklar belirlenmiştir. Buna tüketcilerin eğitim seviyesi arttıkça mobil pazarlamaya yönelik algının poztif seviyede arttığı söylenebilir. Tüketicilerin gelir gruplarına göre yapılan analizde ise, tüketcilerin sadece satın alma kararları etkisi üzerinde istatiksel anlamlı fark belirlenmiş olup böylelikle aylık geliri 15.000 tl ve üzeri olanlar da bu bileşenin etkisi düşük gelir gruplarına göre daha yüksek düzeyde çıkmıştır. Ayrıca, mobil mesaj alma sıklığına göre havayolu yolcu ve müşterilerin mobil pazarlama algıları, kişisel izin ve memnuniyet algısı boyutu haricinde diğer tüm boyutlarda anlamlı bir şekilde değişmektedir. $\mathrm{Bu}$ sonuçlar doğrultusunda, mobil pazarlama uygulamaları kullanan havayolu işletmeleri yolcuları sosyo-demografik segmentlere ayırararak bu segmentlerin özelliklerine göre tutundurma programı düzenleyebilir. Bu nedenle işletmelerin hedef kitlelerini sosyo-demografik özellikleri yönünden tam anlamıyla tanımaları ve bu özelliklerini dikkate alarak mobil pazarlama uygulamalarını pazarlama programlarında kullanmaları havayollarının başarı düzeylerini arttıracaktır. Ülkemizde yerli tursitlerin mobil pazarlama uygulamalarına karşı tutumlarına yönelik yapılan çalışmada (Bilici ve Diğ, 2018), yerli turistlerin sosyo-demografik özellikleri ile turistik ürünlerin mobil pazarlamasına demografik yönden karşı tutumları arasındaki farklılıkları belirlemek için yapılan analizde; bilgilendirme faktörü ile yaş ve eğitim durumu değişkenleri; eğlence faktörü ile eğitim durumu değişkeni; güven faktörü ile 
gelir durumu, medeni durum ve meslek değişkenleri ve yarar faktörü ile gelir durumu değişkeni arasında istatistiksel olarak anlamlı farklılıklar bulunmuştu. Bu manada demografik faktörlerin bu çalışmada da Altı̈̈z ve Bayram (2016) mobil pazarlama ve turzimde mobil teknoljilerin kullanımı hakkında yapıtıkları çalışmanın sonucunda ise; gençlerin mobil cihazlar üzerinden internet yoluyla zamandan ve mekândan bağımsız sosyal bir dünya kurduklarına, Türsab'ın Gençlik Turizmi 2015 y1lı raporuna göre bu gençlerin \%56's1 seyahatleri ile ilgili değerlendirmelerini çevrimiçi ortamlar üzerinde yaptıklarına ve ayrıca gençlerin \%43'ü her 5 dakikada bir cep telefonlarını kullanmakta olduklarına vurgu yaparak rekabet avantajı sağlamak isteyen işletmelerin bu eğilime uymaları gerektiği dikkat çekilmiştir. Bu çalışmada da 36 yaş grubu ve altı \%47 lik bir kesimi oluşturduğu için bu konudaki daha önceki önerinin dikkate alınması gerekmektedir. Çalışmada daha önce benzer araştırmalarda Alkaya (2007), Turan (2011), (Marangoz ve Diğ., 2012), Talih ve Demiralay (2012)'ın bazı bulguları benzer olmakla birlikte aynı sonuçlara erişilmemiştir. Zira yaş ve medeni duruma göre havayolu müşterilerinin mobil pazarlama algıları değişmemekle beraber, cinsiyete göre mobil pazarlamaya yönelik tutumlar, eğitim durumuna göre mobil pazarlamanın tüm boyutları istatiksel olarak anlamlı şekilde değişmektedir. Gelir durumuna göre ise mobil pazarlamanın satın alma kararlarına etkisi anlamlı bir şekilde değişmekte olduğu özellikle üst gelir grubunda (15.000 tl ve üstü) bu farklılığın daha net bir şekilde görüldüğü söylenebilir. Armağan ve Gider'in (2016), Nazilli'de üniversite öğrencileri üzerinde yaptıkları araştırmada üniversite öğrencilerinin satın alma davranışları ile mobil pazarlama ilişkisi incelemesinde katılımcıların satın alma kararlarında mobil reklam içerikli mesajların etkili olduğu sonucuna ulaşılması bu konudaki benzer durumu göstermektedir. Alınan SMS mesajı sıklığ 1 yönünden de kişisel izin memnuniyet algısı hariç olmak üzere mobil pazarlamanın diğer boyutlarında istatiksel olrak anlamlı bir fak belirlenmiştir. Aaraştırma modeli hipotezleri kapsamında ilgili $\mathrm{H}_{2}, \mathrm{H}_{3}$ hipotezleri ret edilirken, $\mathrm{H}_{4}, \mathrm{H}_{6}$ hipotezleri kabul edilmiş, $\mathrm{H}_{1}$ (mobil pazarlamaya yönelik tutumlar) ve $\mathrm{H}_{5}$ (mobil pazarlamanın satın alma kararlarına etkisi) hipotezleri ise ilgili boyut kapsamında kabul edilmişlerdir. Ek olarak yapılan ilişki analizinde demografik faktörlerle tüketiclerin mobil pazarlama mesajlarını alma, kullanma, katılma sıklığı ve alışveriş yapma eğilimlerine yönelik pozitif yönde ilişkiler belirlenmiştir. Buna göre; müşterilerin yaptıkları alışveriş miktarı ile yapılan harcamalar arasında, müşterilerin gelirleriyle yapılan harcamalar arasında, müşterilerin gelirleriyle yaş arasında, internette geçirdiği süre ile yapılan harcamalar arasında pozitif yönlü ilişkiler mevcuttur. Elde edilen bulguların sonucunda müşterilerin mobil pazarlama uygulamalarını kullanma ve katılma sıklığ 1 arttıkça alışveriş yapma ve olumlu tutum değerlendirmelerinin artacağ söylenebilir. $\mathrm{Bu}$ nedenle tüketicilere mobil uygulamları kullanmaları yönelik reklam faaliyetlerine yer verilmelidir. Çalışma ağırlıklı olarak havayolu ile seyahat eden tüketcilerin mobil pazarlama uygulamalarına yönelik algılarının demografik yönden değişip değişmediğinin incelenmesine odaklanmıştır. Buna ilave olarak, tüketiclerin en çok ve hangi sıklıkta mobil araçlarını kullandıkları, hangi araçları havayolu seyahat sürecinin hangi aşamasında kullandıkları; örneğin uçuş öncesi, hava limanı hizmetleri, uçuş süresince, uçuş sonrası gibi ayrıntılı araştırılmasının yapılarak hangi uygulamaların ve nerelerde daha çok yaygın kullanıldığı incelenmesi önerilmektedir. Benzer şekilde havayolu ile seyahat eden yolcuların mobil uygulamalarına yönellik bugünün yaşadıkları sorunları, bunlara yönelik çözümleri ve yarının beklentilerini içeren ayrı bir araştıma yapılması önerilmektedir. Havayolları açısından, benzer iş modelleri kapsamında (tam hizmet ağ taşıyıcıları, düşük maliyetli taşıyıcılar) faaliyet göstere 
havayollarının mobil uygulamalarının kıyaslanması yoluyla havayollarının mobil uygulamalar konusunda etkinliklerinin belirlenmesi çalışmasının yapılmasında da fayda görülmektedir.

\section{KAYNAKLAR}

Airline IT Survey 2017. https://www.sita.aero/resources/type/surveys-reports/airlineittrends-survey-2017 (Accessed: 22.07.2017).

Aksu, A. (2007). Mobil Pazarlama ve Piyasa Etkinliğinin İncelenmesi, Kadir Has Üniversitesi Sosyal Bilimler Enstitüsü İşletme Anabilim Dalı Yüksek Lisans Tezi, İstanbul.

Alkaya, A. (2007). Mobil Kanallar Yoluyla Pazarlama İletişimi Süreci ve Üniversite Öğrencilerinin Mobil Pazarlamaya İlişkin Tutumlarına Yönelik Bir Araştırma. Eskişehir: Anadolu Üniversitesi Sosyal Bilimler Enstitüsü, Yüksek Lisans Tezi.

Altıöz, Ö. ve Bayram, A.T. (2016). Mobil Pazarlama ve Mobil Tekolojilerin Kullanımı,"Uluslararası Sosyal Araştırmalar Dergisi"'Cilt 9, Sayı, 42, Şubat.

Armağan, E., Gider, A. (2014). Mobil Pazarlama Ve Üniversite Öğrencilerinin Mobil Pazarlama Algısı: Nazilli'deki Üniversite Öğrencilerine Yönelik Bir Araştırma, OnlineAcademicJournal of Information Technology, Cilt 5,Say1 17.

Beldona, S., Lin, K., ve Yoo, J. (2012). The roles of personal innovativeness and push vs pull delivery methods in travel-oriented location-based marketing services. Journal of Hospitality and Tourism Technology, 3(2), 86-95.

Beatson, A., Coote, L.V., Rudd, J.M. (2006). Determining consumer satisfaction and commitment through self-service technology and personal service usage. J. Market. Manag. 22 (7/8), 853-882.

Bilici, H., Yokuzman, N., Kılıç, B., Yüksel, F. (2018). Yerli Turusitlern Mobil Pazarlama Uygulamalarına Karş1 Tutumları, "Organizasyon Ve Yönetim Bilimleri Dergisi", Cilt 10, Say1 2.

Buhalis, D., ve Law, R. (2008). Progress in information technology and tourism management: 20 years on and 10 years after the Internet-The state of eTourism research. Tourism management, 29(4), 609-623.

CAPA (2017). Malaysia 2017 aviation outlook: passenger growth may reach $15 \%$ as AirAsia, Malindo \& MAS expand. https://centreforaviation.com/analysis/ malaysia-2017-aviation-outlook-passenger-growth-may-reach-15-asairasiamalindoemas-expand-325115. Accessed 23 March 2017).

Carol A, Barnes S J, Scornavacca E ve Fletcher, K. (2007). Consumer Perception and Attitudes Towards SMS Advertising: Recent Evidence From New Zealand, International Journal Of Advertising,26(1), 79-98.

Elliott, K., Meng, G., Hall, M. (2012). The influence of technology readiness on the evaluation of self-service technology attributes and resulting attitude toward technology usage. Serv. Market. Q. 33 (4), 311-329.

Gardlund, M. (2005). 'A Conceptual Model of Mobile Marketing for a Multinational Consumer Goods Company’. Master of Science Thesis. Stockholm. ss.11. 
Hanley, M., Becker, M. ve Martinsen, J. (2006). Factors influencing mobile advertising acceptance: will incentives motivate college students to accept mobile advertisements?. International Journal of Mobile Marketing, 1 (1): s. 50-58.

İOS Passbook (2014). http://support.apple.com/tr-tr/HT5483, Erişim Tarihi: 11.11.2014

Karaçizmeler Güzeler, A. (2010). Mobil Pazarlama Ve SMS (Kısa Mesaj) Ille Yapılan Reklam Ve Kampanyaların Tüketici Davranışı Üzerindeki Etkilerine Yönelik Bir Uygulama: Şanlıurfa Örneği, Yüksek Lisans Tezi, Sosyal Bilimler Enstitüsü, Şanlıurfa, ss.12.

Karaca, Y. ve Ateşoğlu, İ. (2006). 'Mobil Reklamcılık Ve Uygulamaları: Kavramsal Bir Çerçeve'. Pazarlama İletişimi Ve Kültürü Dergisi. 5.

Keshtgary, M. ve Khajehpour, S. (2011). Exploring and analysis of factors affecting mobile advertising adoption- an empirical investigation among Iranian users. Canadian Journal on Computing in Mathematics, Natural Sciences, Engineeringand Medicine, 2, s. 144-151.

$\mathrm{Ku}$, E.C.S., Chen, C.D. (2013). Fitting facilities to self-service technology usage: evidence from kiosks in Taiwan airport. J. Air Transport. Manag. 32 (2013), 8794.

Leung, D., Law, R., van Hoof, H., \& Buhalis, D. (2013). Social media in tourism and hospitality: A literature review. Journal of Travel and Tourism Marketing, 30(12), 3-22.

Lu, J.L., Chou, H.Y., Ling, P.C. (2009). Investigating passengers' intentions to use technology-based self check-in services. Transport. Res. E Logist. Transport Rev. 45 (2), 345-356

Mak, B., Nickerson, R., ve Sim, J. (2015). A model of attitude toward mobile locationbased services. Journal of Quality Assurance in Hospitality and Tourism, 16(4), 414-437.

Marangoz, M. (2014). İnternette Pazarlama. İstanbul:Beta Basım.

Mobil Marketing Associaition (2009). "MMA Updates Definition of Mobile Marketing”, Erişim Tarihi: 12.08.2015), Erişim adresi: http://mmaglobal.com/news/mma-updates-definition-mobile-marketing

Mickaiel, İ. (2011). "Mobile the new Black for Travel", http://www.zdnet.com/ mobilethe-new-black-for-travel-1339321469/, Erișim Tarihi: 13.11.2014

Nysveen, H., Pedersen, E. P. ve Thorbjørnsen, H. (2005). Intentions to use mobile services: antecedents and cross service comparisons. Journal of the Academy of Marketing Science, 33 (3): s. 330-346.

Pagiavlas, N., Marburger, P., Stratman, M., Young, S. (2005). "MOBILE BUSINESS COMPREHENSIVE MARKETING STRATEGIES OR MERELY IT EXPENSES? A CASE STUDY OF THE US AIRLINE INDUSTRY”, Journal of Electronic Commerce Research, VOL. 6, NO.3.

Papatya, Nurhan (2005). "Tuketici Davranışları İle İlgili Motivasyon Modelleri:Bir Perakende İşletmesinde Temizlik ve Kişisel Bakım Urunlerine Bağlı BirAraştırma", Süleyman Demirel Üniversitesi İktisadi ve İdari Bilimler Fakültesi Dergisi, X,1: 221-240.

Porus, J. and Ricker, J. (2007). Consumer Accettancell, Mobile Advertising and Marketing Conference, New York. 
Scharl A., Dickinger, A. ve Murphy, J. (2005) "Success Factors and Industry Difussion of Mobile Marketing", In Electronic Commerce Research and Applications, vol.4 (1), ss. 159-173.

Sotiriadis, M. D. (2017). Sharing tourism experiences in social media: A literature review and a set of suggested business strategies. International Journal of Contemporary Hospitality Management, 29(1), 179-225.

Tanakinjal, G. H., Deans, K. R.,ve Gray, B. J. (2010). Third screen communication and the adoption of mobile marketing: A Malaysia perspective. International Journal of Marketing Studies, 2(1), 36.

Talih, D. ve Demiralay, T. (2012). "Online Alışveriş Sitelerinde E- Hizmet Kalitesinin Olcumune Yonelik Bir Araştırma”, Hukuk ve İktisat Araştırmaları Dergisi, S.1, s.77-86.

Tam, M.L., Lam, W.H.K. (2004). Determination of service levels for passenger orientation in Hong Kong International Airport. J. Air Transport. Manag. 10 (3), 181-189.

TripAdvisor (2014). http://www.tripadvisor.com/PressCenter-c6-About_Us.html, Erişim Tarihi:15.05.2018.

Tsang, M. M., Ho, S. C. ve Liang, T. P. (2004). Consumer attitudes toward mobile advertising: An empirical study. International Journal of Electronic Commerce, 8 (3): $65-78$.

Turan, A.H. (2011). "İnternet Alışverişi Tüketici Davranışını Belirleyen Etmenler: Planlı Davranış Teorisi (TPB) ile Ampirik Bir Test”,Doğuş Üniversitesi Dergisi, S.1, s.128-143.

Türkiye Mobil Pazarlama Birliği (2011). Mobil Pazarlama Tanıtım Kitapçı̆̆ı. Erişim Tarihi: $\quad$ 03.06.2018, Erişim http://mmaturkiye.org/files/MMATanitimKitapcigi.pdf

Wang, D., Park, S., ve Fesenmaier, D. R. (2012). The role of smartphones in mediating the touristic experience. Journal of Travel Research, 51(4), 371-387.

Yamamoto, G.T. (2011). Mobil Yaşam Ve Uygulamalarl, Isbn: 978-605-62095-2-9, İstanbul.

Yoon, S., Kim, J., ve Connolly, D. J. (2017). Understanding motivations and acceptance of locationbased services. International Journal of Hospitality \& Tourism Administration, 1-23. doi:10.1080/ 15256480.2017.1305316.

http://www. hypeistanbul.com/pegasus-case-study, 2018. 


\title{
Analysis of Airline Mobile Marketing Implementations' Perception As Per Passengers' Demographic Traits
}

\author{
Vahap ÖNEN \\ İstanbul Okan University \\ Faculty of Applied Sciences \\ İstanbul, Turkey \\ orcid.org/0000-0001-8592-9430 \\ vahap.onen@okan.edu.tr
}

\section{Extensive Summary}

\section{Introduction}

Information and communication technologies (ICTs) have greatly influenced the accommodation and tourism industry since its emergence in the early 1990s (Buhalis and Law, 2008). The effects of ICTs are mainly based on web sites, social media and mobile technologies (Leung, Law, van Hoof and Buhalis, 2013; Sotiriadis, 2017), which are key channels for industrial practitioners to reach their customers. The mobility of combining and the virtues of mobile technologies such as BITs, smartphones, tablets and mobile applications have become the primary devices for users to access the internets and become an indispensable part of consumers' daily lives (Wang, Park, and Fesenmaier, 2012). According to Statista (2017), the number of smartphone users will exceed 2.8 billion worldwide by 2020 , representing more than a third of the world's population. Mobile marketing is the marketing of products and services over a mobile communication channel. It is a personal, time- and space-sensitive channel that can reach immediate, interactive, or targeted communication with the target audience (Gardlund, 2005, p.11).

This marketing method is called activities that are necessary for communication with customers through the use of mobile devices to increase the sales of products, services and information about these products / services (Karaca and Ateşoğlu, 2006). Recent technological developments in the service sector have led to the transformation of service delivery into face-to-face and self-serving constructs (Lu et al., 2009). By using self-service technologies such as the internet, passengers can use services on their own instead of directly interacting with the employees in the airline industry $(\mathrm{Ku}$ and Chen, 2013; Beatson et al., 2006; Elliott et al., 2012; Lim, 2012; Other, 2009, 2011, Tam and Lam, 2004). Most passengers (87\%) use mobile technology for reservations, and more than half $(54 \%)$ opt for self-service technologies for worldwide check-in services (Airline IT Survey, 2017; www.sita.aero). Airlines offer a range of mobile applications and tools that provide various functions throughout the travel process (Pagiavlas et al., 2005). In Turkey, all airlines, especially Turkish Airlines, Pegasus, Atlas, Sun-Express, Honor, have been following mobile marketing applications at certain levels. Mobile marketing applications are expected to become more and more extensive utilizaiton in the airline industry. For this reason, this study which is analysis of airline's mobile marketing perception in terms of its customer's demographic traits, should be carried out. 


\section{Data Collection and Methodolgy}

The reseach hypothesis has been stated as follows:

$\mathrm{H}_{1}$ : Airline passenger's mobile perception is being changed as per gender type

$\mathrm{H}_{2}$ : Airline passenger's mobile perception is being changed as per marital status

$\mathrm{H}_{3}$ : Airline passenger's mobile perception is being changed as per age group

$\mathrm{H}_{4}$ : Airline passenger's mobile perception is being changed as per edutaion status

$\mathrm{H}_{5}$ : Airline passenger's mobile perception is being changed as per income group

$\mathrm{H}_{6}$ : Airline passenger's mobile perception is being changed as per frequency of receiving mobil message.

There are positive and significant correlations in terms of customer demographic traits, receiving mobile message, usage frequency, buying from mobile web sites and mobile expenditures.

The research was conducten in İstanbul by airline passengers who previously purchased ticket and flew. The face to face survey performed by by 419 passenger as convenience sampling method then 400 of them found acceptable. In the study Aalkaya's mobil marketing scales which is Likert Type ( $1=$ strongly agreed, $5=$ strongly disagreed) is used.

\section{Findings and Discussions}

As a result of the factor analysis, the KMO value was 0,77; For factor analysis, the Barlett's test, which showed the existence of an adequate relationship between the variables, showed a result of 0,000 , which is significant at $p<.001$. As a result of the factor analysis 4 questions were omitted from the related scale. The mobile marketing scale has reached a level that accounts for $69 \%$ of the total variance in 4 dimensions. In this context, number 1 dimension is called mobile marketing influences on purchasing decisions, number 2 dimension is personal permission and satisfaction perception, number 3 dimension is an overview of mobile marketing activities, and number 4 dimension is called attitude towards mobile marketing applications.

According to the analysis of the independent " $t$ " test conducted, only the attitude towards mobile marketing showed that $\mathrm{n}$ is significant at the $95 \%$ confidence level $(\mathrm{p}=$ $0,027<0,05)$ according to the genders of the participants. In the study conducted, it was determined that the interest in mobile marketing for female consumers was higher than that for men, and the relevant $\mathrm{H}_{1}$ hypothesis was accepted only at this dimension. According to the results of the one-way analysis of variance, the statistical significance values of the dimensions are; $(p=0,40 ; 0,25 ; 0,53 ; 0,48)$, and since these significance values are greater than 0.05 in the $95 \%$ confidence interval, the relevant $\mathrm{H}_{2}$ hypothesis was rejected and the airline passengers and customers marketing perceptions have not changed. According to the results of one way variance analysis for age groups, tatistical significance values in mobile marketing dimensions are; $(p=0,54 ; 0,06 ; 0,11 ; 0,76)$ In the $95 \%$ confidence interval, the significance values are greater than 0,05 the relevant H3 hypothesis was rejected and the airline passengers and customers marketing perceptions have not changed. The mean values and standard deviations obtained in all dimensions in the one-way variance analysis according to the education groups are 
shown and statistical significance is determined in all dimensions in terms of the whole education factor and the related $\mathrm{H}_{4}$ hypothesis is accepted. A statistical significance difference of $F=4,912,(p=0,01<0,05)$ was found as a result of the variance analysis for effecting the purchasing decisions of mobile marketing. The Tukey test was used in Post Hoc tests to determine the source of the difference. The mean values and standard deviations of all dimensions in one way analysis of variance according to income groups are shown in Table 11. The statistical significance of $F=4,240(p=0,00<0,05)$ was determined as the result of the variance analysis for the effect of the mobile marketing only on the purchasing decisions in the analysis made. Only the related $\mathrm{H}_{5}$ hypothesis was accepted at this dimension. In the one-way ANOVA analysis, the mean values, standard deviations obtained in all dimensions are shown in Table 12 and statistical significance was determined in all other dimensions except for the personal permission and satisfaction perception dimension, and the related $\mathrm{H}_{6}$ hypothesis was determined for the other three dimensions It is accepted. As a result of the variance analysis, the statistical significance was determined as $F=6,107(p=0,00<0,05)$ for the effect of mobile marketing on purchasing decisions. The Tukey test was used in Post Hoc tests to determine the source of the difference. As a result of the analysis made, it was determined that there is no significant difference in customers' mobile marketing perceptions according to gender status and age groups. In the analysis made according to the educational status, it was determined that mobile marketing perception was perceived differently in all dimensions, according to the income groups; it was seen that there was a significant difference only in the effect of mobile marketing on purchasing decisions, according to the frequency of receiving messages, there were statistically significant differences in the dimensions of the impact of mobile marketing on purchasing decisions, the interest in mobile marketing and the overall view of mobile marketing activities. In generally summarized, it is determined that mobile marketing perception has changed more than one demographic traits.

There was a negative correlation between the tendency of airline customers to make online purchases with the frequency of receiving mobile messages $\left(\mathrm{r}=-, 31^{* *}\right)$. A significant and positive correlation was found between the amount of shopping made by the customers and the average amount of money spent on this exchange $(r=, 519$ **). A significant and positive relationship was found between the income and the age of the customers $(\mathrm{r}=, 348 * *)$, the average amount of money spent on the bookings and the customers' income $(\mathrm{r}=, 392 * *)$. A positive and significant relationship was found between the amount of shopping made and the average time spent by the consumers on the internet $\left(\mathrm{r}=, 144^{* *}\right)$. A significant positive correlation was found between the average amount of money the customer spent on the internet and the amount of money they spent on shopping $\left(\mathrm{r}=, 109^{* *}\right)$. According to these results, it is found that there are significant and positive correlations between purchased items and customer expenditures, between customers incomes and customers expenditures; between customers ages and customers incomes; beween avereage internet usage duration and customers expenditures. 